\title{
Article
}

\section{Open Innovation and Serial Entrepreneurs}

\author{
Jinhyo Joseph Yun ${ }^{1, * \mathbb{C}}$, MinHwa Lee ${ }^{2, *}$, KyungBae Park ${ }^{3}$ and Xiaofei Zhao ${ }^{1}$ \\ 1 Department of Open Innovation and Business Model Research, Daegu Gyeongbuk Institute of Science and \\ Technology (DGIST), Daegu 42988, Korea; qiaoke@dgist.ac.kr \\ 2 Department of Intellectual Property, KAIST, Seoul 34142, Korea \\ 3 Department of Business Administration, Sangji University, Wonju, Gangwon-do 26339, Korea; \\ kbpark@sangji.ac.kr \\ * Correspondence: jhyun@dgist.ac.kr (J.H.J.Y.); minhwalee@kaist.ac.kr (M.H.L.); Tel.: +82-10-6697-8355 \\ (J.H.J.Y.); +82-10-3791-4470 (M.H.L.)
}

Received: 23 June 2019; Accepted: 11 September 2019; Published: 16 September 2019

\begin{abstract}
With the advent of the Fourth Industrial Revolution, the role of entrepreneurs has become more crucial than ever. As a result, an open innovation model is suggested here that can promote serial entrepreneurs by answering the following question: "How does the serial entrepreneur in open innovation conditions continuously identify business opportunities?" This question is answered through an in-depth case study of Medison from 1985 to 2016, as Medison is not only a representative Korean medical device company, but is also a representative example of serial entrepreneurship in Korea. First, we examined the diverse open innovation channels, such as spin-offs, venture investment, and joint venture, used by Medison before it was merged with Samsung. Second, we examined the open innovation serial entrepreneurs of Medison and then analyzed the direct serial entrepreneurs of Medison. Fourth, we built a causal loop model of Medison open innovation with emergence and complexity combined. Finally, a sustainable open innovation strategy and an approach to sustainable serial entrepreneurship was formulated. The foundation of this research is as follows. First, an open innovation strategy can be a strong motivator for serial entrepreneurs. Second, a balance between emergence and complexity is required to trigger sustainable serial entrepreneurs of open innovation.
\end{abstract}

Keywords: open innovation; serial entrepreneur; spin-off; venture investment; joint venture

\section{Introduction}

The Fourth Industrial Revolution is characterized by growth without employment, or the end of work, which requires governments to not only fix the market but also to form a market [1-3]. Hence, the creation of jobs by start-ups is a critical issue, because start-ups can influence the creation of new jobs in new industries. However, the survival rate of start-ups is very low: for five years, the rate is just under one-fifth, even in entrepreneurial states such as Israel or Finland [4,5]. Under special conditions, serial entrepreneurs can achieve high start-up survival rates [6]. Intrapreneurship has also long been identified as a means to increase the innovation ability of firms and could be scalable to respond to the challenge of managing a massive internal start-up call [7].

Differences exist between intrapreneurship and entrepreneurship. Nascent entrepreneurs tend to leverage their general human capital and social ties to organize ventures that work directly with customers, whereas intrapreneurs disproportionately commercialize unique new opportunities to sell to other businesses [8]. With the emergence of the second information technology (IT) innovation, the foundation of a new business model based on the creative recombination of technologies and markets has become a driving force to overcome the stagnation of capitalist growth $[9,10]$. Therefore, the role of entrepreneurs who newly combine the relationship between technologies and markets in their start-ups has become increasing crucial, as Schumpeter pointed out, because an entrepreneur is not an "inventor" 
of the good or process, but an "innovator" who combines new factors [11]. However, due to limited knowledge as well as Schumpeterian irony, "planning cannot be innovation", so entrepreneurial functions will become obsolete and atrophic [12].

Thus, the establishment of serial entrepreneurs, in which existing entrepreneurs continue to establish new companies under certain conditions, is an effective method for mitigating the obsolescence of the entrepreneurial function [13]. The group of entrepreneurs that emerged following the sale of PayPal for USD $\$ 1.5$ billion in 2002, some of whom have subsequently launched other successful start-ups, was dubbed the "PayPal Mafia" [14]. In Korea, Medison (currently, Samsung Medison in Seoul, Korea), a leading global information technology (IT) healthcare firm, has also fostered the emergence of many serial entrepreneurs, known as the "Medison Mafia". Medison is famous for its diverse open innovation strategies and when it reached its sales peak before becoming a Samsung member firm $[15,16]$. Medison is not a representative firm in Korea for research on serial entrepreneurs, but it does provide a special case in two aspects: its all-area open innovation strategies in the 1990s and its serial entrepreneurs that were continually produced right up until 2016, even after it had been acquired by Samsung in 2011.

\subsection{Research Questions}

If we want to fully understand entrepreneurship, we need to consider the relationship between the entrepreneur and his/her environment, because an entrepreneur creates and develops a new enterprise by interacting with the environment, including the open innovation strategy of the firm [17]. Open innovation means that valuable ideas can come from inside or outside the company and can also enter the market from inside or outside the company [18]. Open innovation includes several channels, such as inside-out through spin-off; outside-in, such as in venture investment; or coupled, such as with joint ventures [19]. However, research gaps exist on the subjects of serial entrepreneurs and open innovation, so research on the relationship between open innovation and serial entrepreneurs help reduce the research gap. Serial entrepreneurs compose 30\% of all entrepreneurs [6], but until now, the path to achieving serial entrepreneurship has not been well researched. By narrowing this research gap, we will theoretically understand the path(s) to serial entrepreneurship. The research question of this study was: "How does a serial entrepreneur in open innovation conditions continuously identify business opportunities?"

Despite various attempts to achieve the success of entrepreneurs with creative business models, most policies and strategies have not succeeded in Korea, as the annual unemployment ratio of South Korea increased for 10 years from 2008 to 2017 even though the unemployment rate of quarter 1 in 2019 of Korea was 4.0, which was not that high compared to other Organization for Economic Cooperation and Development (OECD) countries. However, Medison's open innovation strategies were nurtured in 101 serial entrepreneur firms (the Medison Mafia) until 2016, according to an interview with Medison founder Dr. Lee. Medison has operated diverse strong open innovation strategies since the 1990s. Thus, this study focused on the serial entrepreneurs at Medison and addressed the following research questions: "(1) How did open innovation strategies motivate so many serial entrepreneurs at Medison? (2) What is the mechanism by which open innovation triggers serial entrepreneurs at Medison?"

\subsection{Research Scope and Method}

This study involved an in-depth case study of Medison, a representative Korean medical device firm. Medison, one of the leading ultrasonic diagnostic device manufacturers in the global market and a pioneering Korean venture company, was established in 1985 and was acquired by Samsung in 2011.

The research scope of this study was as follows. We analyzed Medison and its serial entrepreneur firms from 1985 to 2016 [20,21]. First, we examined the various open innovation strategies used by Medison before acquisition by Samsung. At the time, Medison actively implemented open innovation strategies. Second, we considered how the start-ups of spin-outs, venture investments, and joint venture companies, which are open innovation channels, emerged through the open innovation of 
Medison. Third, we analyzed companies founded by people who had previously worked at Medison. Fourth, we investigated how the companies were established from Medison's open innovation channel start-ups. The study concludes by suggesting a suitable open innovation model that can promote the creation of serial entrepreneurs.

This study used in-depth interviews as the basis for its qualitative research on the target case study. The purpose of in-depth interviewing is not to test or to evaluate hypotheses, but to understand the lived experience of other people and the meaning they create from their experiences [22]. Even though interviews are time-consuming and expensive, we used them to understand and discover the meaning of open innovation and serial entrepreneurship at Medison. Additionally, this research used a semistructured questionnaire that is used extensively in social research for in-depth interviews because of its efficiency and the ability to compare the interview results (Appendix A) [23,24]. We interviewed representative entrepreneurs in our research field, such as those from the open innovation channel, including the founder of Medison, those who worked at Medison, and those produced by an open innovation channel at Medison. Interviewee candidates were selected from all open innovation channels by research teams in addition to the Medison founder and were finalized by the agreement of interviewees. As shown in Appendix B in "in-depth interviewee list with main contents", we conducted in-depth interviews over a period of approximately one year, from November 2016 to October 2017. In summary, we used an intrinsic and collective case study by interviewing several serial entrepreneurs at Medison to understand the meaning of open innovation at Medison [25].

Interviewees were encouraged to focus on concrete details and were asked to reconstruct memories and evidence [25]. In addition, we analyzed the open innovation strategies of Medison through an in-depth interview with Professor MinHwa Lee, the founder of Medison. This included various materials and internal information not disclosed to the public.

\section{Literature Review and Research Framework}

Again, an "entrepreneur" was defined by the economist Schumpeter as an innovator who leads diverse new combinations in technology, the market, etc., which is different from a set of personality traits or the creator of organizations, and this has been at the center of economic and public policy since the beginning of the 1980s [26,27]. Small companies with roots in entrepreneurship, including start-ups, struggled to cope with several economic crises after World War 2; nevertheless, entrepreneurs have persisted [28]. Although entrepreneurs employing creative destruction are more than just alert to opportunities created by others, according to a Schumpeterian perspective, the main role of the entrepreneur is to drive the discovery of previously unknown profit opportunities [29]. This implies an alertness to what might be a possible opportunity, in other words, the sense to recognize opportunities that have not previously existed at all [30].

"The PayPal Mafia who are well-known example of serial entrepreneurs were created from the sale of PayPal chose not to retire, but instead started new firms" [31]. This group of serial entrepreneurs and investors reflected the characteristics of Silicon Valley, where successful ventures and easy access to capital motivate ambition and further success. Associated with the new start-ups founded by the PayPal Mafia were several billionaires such as Elon Musk, Reid Hoffman, Jeremy Stoppelman, Russel Simmons, and Peter Thiel.

Serial entrepreneurs differ from novice entrepreneurs and portfolio entrepreneurs [20]. Unlike novice entrepreneurs, serial entrepreneurs are not the first owners of an independent business, and whereas portfolio entrepreneurs have stakes in two or more independent businesses, serial entrepreneurs have ownership in only one. Serial entrepreneurs are continuous business starters who, in the past, have finished a business and currently run a different new business [6,21]. An employee with entrepreneurship skills is likely to become an entrepreneur subsequently rather than remain an employee [6]. With increases in venture capital (VC), more entrepreneurs have chosen to leave their initial enterprises, thereby creating new start-ups with the potential to embark on subsequent ventures [13]. The major investment targets of venture capitalists are serial entrepreneurs [13]. 
Investments in serial entrepreneurs account for $48.7 \%$ of all investments in England. In a study of technology commercialization conducted by a Canadian college, $12 \%$ of professors chose repeat commercialization and repeatedly executed $80 \%$ of technology commercialization. Thus, initiators of repeat commercialization are habitual (or parallel/serial) entrepreneurs in that they have the ability to create inventions and the ability to earn resources for the commercialization of those inventions [32]. That is to say, even though there is not one definition of a serial entrepreneur, it means a person who has experience in starting an independent or intraventure start-up builds up a new firm again.

Although replicate entrepreneurship—producing or selling goods or services that already exist elsewhere-is an important route out of poverty, innovative entrepreneurs who can motivate economic growth with companies growing from creative destruction are equally important [33]. Thus, governments should motivate successful replicant entrepreneurs to continue to innovate and grow-that is, to become serial entrepreneurs-to create a well-functioning entrepreneurial economy [33].

Serial entrepreneurs are triggered by their resource potential, such as knowledge potential obtained from relationships and experience; their financial resources potential, which is derived from financial aid from institutions or seed money from another entrepreneur; or their relationship potential, which is based on information relationships with colleagues or other enterprises [34].

Open innovation involves three core processes: (1) the outside-in process, enriching a company's own knowledge base; (2) the inside-out process, the external exploitation of ideas in different markets; and (3) the coupled process, linking outside-in and inside-out by working in alliance with complementary companies [35]. Spin-out, or spin-off, refers to an inside-out open innovation process that pursues new markets [36,37].

Spin-outs differ from an in-company growth strategy and a business strategy under the umbrella of a single big company. The spin-out approach is more appropriate for high-tech start-ups than a diversification strategy in that high-tech companies spun off from universities occupy critical junctures in developments [38]. The survival and development of spin-outs depends on how they withstand these critical junctures. In an open innovation process of starting new organizations that draw on internal knowledge, which uses spin-off and spin-out processes, the parent firms may provide finances, human capital, legal advice, and administrative services in addition to knowledge to the spin-out firms [39].

Corporate venture investments provide an opportunity to grow as a channel of open innovation strategy that avoids the threat of optimism as a result of lock-in situations rather than being a threat themselves [40]. A strong relationship between a VC and the parent company at the industry level leads to a strong relationship between venture investments and high innovation at the companies [41]. Open innovation of corporate venture investments in risk-laden activities has the following advantages: (1) the benefits of early involvement in new technology-based businesses, (2) the postponement of financial commitments, (3) early exits that diminish losses, and (4) delayed exits in the event that a venture is spun off [42]. Venture investment is a channel that provides an opportunity for a new business with innovative new technology [35]. In the same context, VC firms with better networks can be better rewarded for performance, as measured by a successful exit ratio through an initial public offering (IPO) or sale to another company [43].

Joint ventures, partnerships, or codevelopment can increase the return from internal R\&D by leveraging the partner's capabilities [44]. Codevelopment partnerships, or joint ventures, are a kind of coupled open innovation channel that can increase both profitability and innovation capability [35,44]. Joint ventures can serve as open innovation channels when competition eclipses cooperation if their transaction costs can be controlled [45]. When a partner firm has a higher density, the host firm will be more likely to choose a joint venture as opposed to a wholly owned subsidiary [46]. When a firm does not have enough information about a new sector with a different culture, it can choose a joint venture with another firm that knows the sector well, especially in foreign countries [47,48]. Building joint ventures via networking as a strategy change is popular in the mobile phone sector [49]. 
Open innovation culture studies have expanded from the research on the not invented here (NIC) syndrome of Katz and Allen [50,51]. Opening up the innovation process starts with a mindset, which in other words is open innovation culture [52]. If different innovation strategies require different cultures, open innovation should require an open innovation culture [53,54]. That is, open innovation can be motivated in a culture characterized by openness because people with diverse backgrounds in the innovation process increase the ability of responding rapidly to changing markets and technology [52]. Creating a culture that values outside competence and know-how is crucial for open innovation practice [52]. An open innovation culture is required to undertake continuous innovation and enhance corporate performance in the environment of open innovation culture [55]. Joining other groups in the firm through open innovation is one of the key strategies for overcoming existing cultural barriers [56]. For any firm to stimulate and sustain creativity and innovation, it is necessary to have a culture that is open to something different from the firm's current conditions [57].

Open innovation culture decreases differences within companies and increases the likelihood of a successful business model [58]. Companies that have diverse components in their agenda, workforce, or activities can be more innovative when the internal openness to differences is high compared to a company with monotonous components with an open or closed culture [59]. Thus, openness to innovation, or an open innovation culture, encourages seeking the unexpected and disruptive solutions [60]. Therefore, different levels of culture in companies are the driving force of new and different innovations in a new age in enterprises.

An open innovation-friendly culture motivates serial entrepreneurs in addition to triggering open innovation because an open innovation-friendly culture, like the transcendental-live firm culture of Medison, can also increase intraventure behavior and teams [51,60]. Open innovation channels, such as spin-out (or spin-off), venture investments, or joint ventures, are not totally independent new start-ups because much of the finance and workforce is connected to the parent firm. However, open innovation channels are similar to new start-ups in that they follow nearly all processes of start-ups. Therefore, we called the open innovation start-up pseudo-serial-entrepreneur-like (Figure 1) open innovation in the serial entrepreneur research framework.

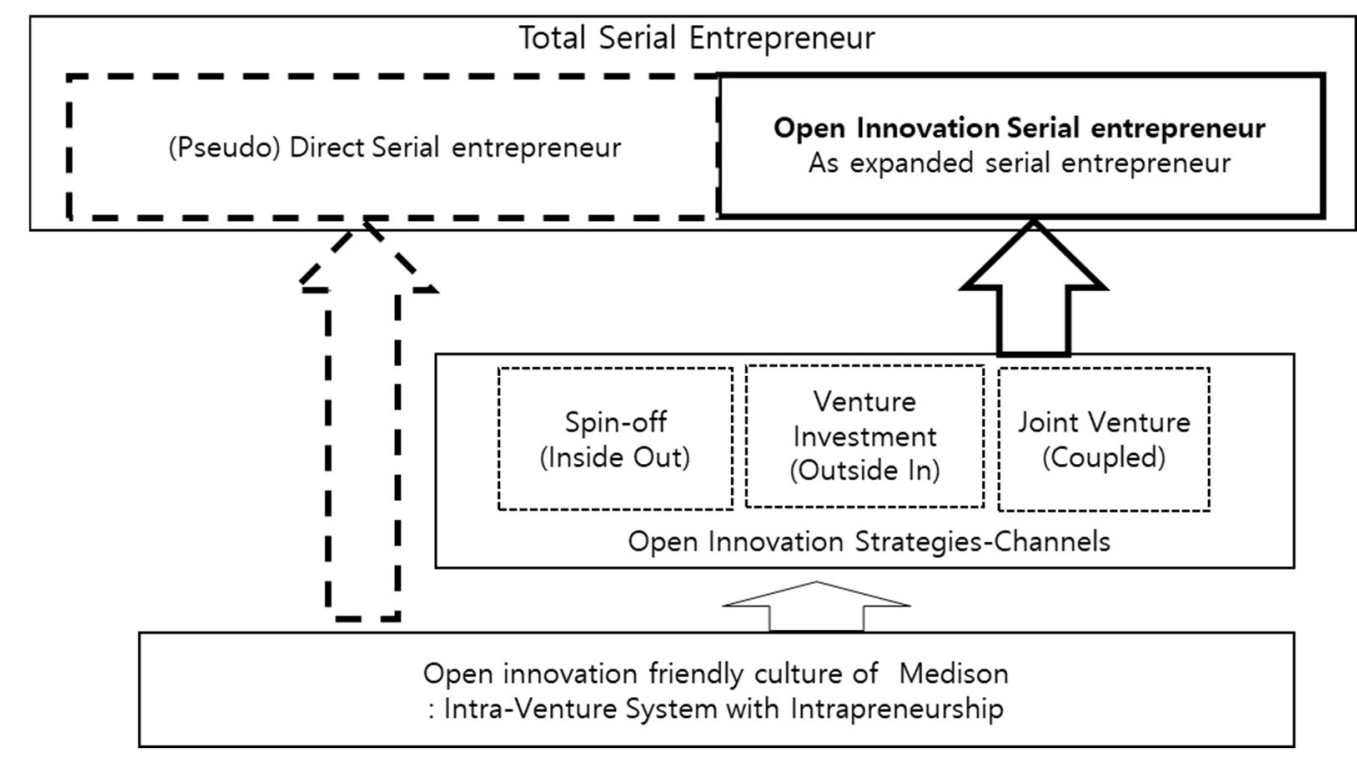

Figure 1. Open innovation in serial entrepreneur research framework.

Serial entrepreneurs could be divided into two categories: pseudodirect serial entrepreneurs and open innovation serial entrepreneurs. An open innovation serial entrepreneur refers to anyone who had worked as a chief executive officer (CEO), chief technology officer (CTO), or start-up team member at open innovation channels and started his or her own new start-up, as in the right side of Figure 1. 
A (pseudo)direct serial entrepreneur was anybody who had worked as a leader of an intraventure team at Medison, or the CEO of Medison, who had started his or her own new start-up(s), as in the left side of Figure 1. Even though the leader of an intraventure is not a CEO, he/she is a kind of pseudo-CEO, and we call the CEO or leaders of intraventures of Medison pseudo direct serial entrepreneurs.

The number of Medison serial entrepreneurs has been higher than others because not many have been direct serial entrepreneurs only, but many have been open innovation serial entrepreneurs.

In this study, we analyzed the real dynamics of serial entrepreneurs at Medison from deep interviews based on the Figure 1 research framework, which included an open innovation-friendly culture, three open innovation channels, and open innovation serial entrepreneurs and direct serial entrepreneurs.

\section{Open Innovation-Friendly Culture and Three Open Innovation Channels of Medison}

All nine interviewees in Appendix B talked about a diverse open innovation-friendly culture and related systems or strategies such as a failure acceptance culture, the high intraventuring attitudes of all departments, high intra-entrepreneurship, the separate floor location of differently functioning departments, and "the transcendental-live firm culture or strategy", among other things.

Medison acquired Kretz (Paris, France), a three-dimensional (3D) source technology firm, in 1997, even though global companies such as HP or Toshiba hesitated at the merger and acquisition (M\&A). This acquisition was the first success of the open innovation strategy in the history of Medison, which motivated the open innovation-friendly culture at Medison. The first open innovation strategy of Medison significantly decreased the 3D scanning time from $30 \mathrm{~min}$ to $0.05 \mathrm{~s}$ at Medison and in the medical instrument industry.

Medison promoted the transcendental-live firm culture, that is, a network-building culture through open innovation channels involving diverse companies in the medical technology, medical information, and biotechnology fields, with Medison's domination of the domestic market creating the platform for a successful exploration of overseas niche markets. In other words, a general medical ecosystem was formed by Medison with the open innovation strategies of spin-outs, venture investments, and joint ventures. The transcendental-live firm culture of Medison was an open community that promoted shared values, shared information, and shared benefits as its central goals. It was, therefore, a type of open platform. Medison enhanced its internal market competitiveness through autonomy, competitiveness, and intraventure and also promoted the transcendental-live firm strategy through open innovation, referred to here as joint venturing. A transcendental-live firm is one in which every individual corporate element forms part of a single life form (holistic) and where each element represents the entire organization. Therefore, the transcendental-live firm culture means an open innovation-friendly culture, an open platform, and a high-level open innovation strategy (according to M.H. Lee, M.S. Go, B.I. Cho, J.T. Kim, and Y.S. Cho) (Appendix B).

Medison's spin-off strategy motivated entrepreneurship in sectors not related to the core competencies of its head office, in addition to the core competencies themselves. Thus, the spin-outs of Medison differed from spin-outs of other firms: even though normally separate parts that are not strategically important are spin-outs, Medison did not hesitate to spin out the core parts [61]. The spin-outs of Medison can be classified as spin-outs of project teams and functional departments (Appendix C). Among these, UBCare was a typical project team spin-out company, according to an interview with J.T. Kim (Appendix B). This was the first corporate venture company to come from Medison. J.T. Kim, the former CEO of UBCare, was enrolled in a doctoral course in medical engineering while working at Medison. Kim led the Picture Archiving and Communications System (PACS) team, which converted images from the ultrasonic diagnosis system into digital files and saved and processed them. Kim said that he suggested a start-up to Medison, and Medison provided all the necessary aspects for its foundation, such as its resources, brand, and sales networks, and created a team to start the company, with three doctoral students joining the project. Medison built a system that provided feedback on the achievement of the spin-out company while taking approximately $40 \%$ of the shares 
in UBCare in exchange. One of the main markets for Medison was ultrasound systems, but UBCare was an IT company. The two companies had different characteristics in terms of strategies, marketing, and advertisements. The spin-out of UBCare became an important source of momentum that led to the development of various independent divisions, which would soon be spin-outs at Medison. Although it was a new spin-out company, UBCare could use Medison's brand and continuously secured good human resources from Medison. These points provided UBCare with an opportunity to constantly grow as a medical IT firm. The company went public and is now a subsidiary of the SK Group and has grown to be a symbol of the Korean medical IT sector.

After UBCare, various project team-based spin-out companies appeared, such as Meridian (Appendix C) from the DongSeo medical device development team, MGB ENDOSCOPY (Appendix C) from the Rigid Borescope team, BeMeMs (Appendix C) from the X-ray team, or Medison Econet (Appendix C) from the Econet division. In addition, there were several Medison function division spin-outs, such as Medinus Co. Ltd. (Appendix C) from the magnetic Resonance imaging (MRI) division, Medison X-ray (Appendix C) from the X-ray department, Welson Endo Tech (Appendix C) from Endoscope Medical Devices, Surtech (Appendix C) from medical device after service (A/S), M2Comm (Appendix C) from the marketing team, IT@Venture (Appendix C) from the computing department, and Future Communications (Appendix C) from Medison public relations.

$\mathrm{M} 2 \mathrm{Comm}$ was a representative spin-out from the marketing functional department of Medison, according to B.I. Cho (Appendix B). A spin-out from a project team or a business department is common in global companies, but rare from a functional department. A rare and similar example is the functional team spin-out of the patent development research team at a college [62]. ByeongIl Cho, CEO of M2Comm, stated that Medison pursued a strategy of increasing internal corporate ventures through its experimental spirit and through the founding of a start-up from a functional department (Appendix B). M2Comm was spun off with the aim of strengthening the online business and medical IT company marketing for Medison and other medical firms. In other words, the spin-out occurred with the clear goal of expanding the IT-based industry.

Other rare examples of start-ups of functional departments from Medison are IT@Venture from the computer department, Future Communications from the public relations department, and Surtech from the medical device repair department. The start-ups from the functional department set the goal of expanding or improving new medical IT services provided to the IT industry in addition to their functions performed at Medison. Cho said that he continuously implemented entrepreneurship obtained from Medison: the promotion of diversification, for example, meant business service nonmedical markets such as the warehouse of a training center and the silver industry in addition to its business sector of medical marketing and its online business.

Medison aggressively focused on venture investments in the sectors necessary for the future of IT medical devices or those related to their future business, despite these areas not being their core competencies, according to interviews with M.S. Go, M.H. Lee, and an anonymous interviewee (Appendices B and C). The investment was led by MinHwa Lee, founder and CEO of Medison, and its planning team supported the investment. The venture investment companies with diversification characteristics were Osang Healthcare (Appendix D), which handled blood analyzers; Viewworks (Appendix D), which handled X-ray images; Osteosys (Appendix D), which handled bone mineral densitometers; AG Bio Diagnosis (Appendix D), which developed an artificial heart; JVM (Appendix D), which handled drug-packing machines; Viromed (Appendix D), which developed gene therapies; DRTech (Appendix D), which handled X-ray detectors; Scimedix (Appendix D), which handled MRI; Kormed (Appendix D), which handled lithotripters and produced C-arms; and Taeha Mecatronics (Appendix D), which produced treadmills.

Medison's venture investments also covered IT companies in various ways, although there were not many diversification characteristics. Examples include Bit Computer (Appendix D), Hancom (Appendix D), Softcamp (Appendix D), and Muhan Investment (Appendix D). 
The several investments by Medison in sectors with strong or weak diversification characteristics caused conflicts within its venture ecosystem. Conflicts of interest existed between subcompanies such as Bionet, Mediana, and MEK-ICS for patient monitoring systems, and between companies such as Viewworks, DRTech, and COMED with regard to X-ray systems, according to an anonymous interviewee, M.S. Go, and others.

Most interviewees reported that the activation of venture investments by Medison produced strong incentives to provide direct and indirect experience, know-how, and motivation for related departments and members of Medison to initiate start-ups.

With the capabilities accumulated through business diversification, Medison established a strategic alliance or organized a joint venture with biotechnology companies in the 2000s. For example, Prosonic (Appendix E), together with Medison, handled proven ultrasonic transducers. Others included Infinitt (Appendix E) of PACS and Biosys (Appendix E) of Biosignal. In addition, Medison created joint ventures with Cyber KAIST (Appendix E), which handled online education; EZMEDICOM (Appendix E) for medical distribution; Medilinx (Appendix E) for medical business to business (B2B); and Korea Internet Holdings (Appendix E), an Internet venture holding company, to expand its areas through business diversification efforts. The joint venture investments by Medison played a role in completing the venture ecosystem of the transcendental-live firm (Appendix E). The reason for this synergy value creation through diversification was not limited to Medison, as it also adopted an open economy with regard to outside firms.

The open innovation strategy and the three open innovation channels-spin-offs, venture investments, and joint ventures-significantly contributed to strengthening the entrepreneurship of Medison members, who directly and indirectly accumulated experience from start-ups and increased the desire to found start-ups. For the effects of open innovation channels, all interviewees reported the following two aspects. First, those people who were involved in open innovation channels directly obtained experience in the area of creating a start-up from the beginning to the end. Their experiences differed from the entrepreneurship that could be gained through start-up education courses. The start-ups could secure good talent, which is generally difficult for start-ups, using the brand power and background of Medison in Korea. In addition, the people who passed through the open innovation channel could sell their products in global markets as well as in the Korean market through the Medison sales network. They had opportunities to engage in various businesses, as required by start-ups, by fully raising funds through Medison. Second, the members of Medison could gain indirect start-up experience through internal corporate ventures and the constant and direct exchange of information with the start-ups built through the open innovation channels of Medison, thus broadening their experiences.

\section{Open Innovation Serial Entrepreneurs}

Open innovation serial entrepreneurs refers here to entrepreneurs who experienced start-up creations through Medison open innovation channels such as spin-offs, venture investments, and joint ventures and established new medical corporations by themselves (Table 1). 
Table 1. Medison's open innovation serial entrepreneur list.

\begin{tabular}{|c|c|c|c|c|c|}
\hline No. & Firm & $\begin{array}{l}\text { Start-Up } \\
\quad \text { Year }\end{array}$ & $\begin{array}{c}\text { Relationship with } \\
\text { Medison }\end{array}$ & $\begin{array}{l}\text { Founder and } \\
\text { Others }\end{array}$ & Business Field \\
\hline 1 & MEK-ICS & 1998 & $\begin{array}{l}\text { Joint venture investment; } \\
\text { chief technical officer } \\
\text { (CTO) of Biosys }\end{array}$ & $\begin{array}{l}\text { J.C. Kim; a } \\
\text { listed company }\end{array}$ & $\begin{array}{l}\text { Intensive care unit (ICU) } \\
\text { monitoring system, } \\
\text { respirators }\end{array}$ \\
\hline 2 & Medicore & 1999 & $\begin{array}{l}\text { Venture investment } \\
\text { company; CEO of } \\
\text { Median }\end{array}$ & $\begin{array}{l}\text { Y.S. Cho; } \\
\text { Medison's } \\
\text { stake }\end{array}$ & $\begin{array}{l}\text { Medical infrared } \\
\text { thermograph system, } \\
\text { cardiac output system, } \\
\text { blood pressure gauge }\end{array}$ \\
\hline 3 & IRM & 2014 & $\begin{array}{l}\text { Spin-off; chief of the } \\
\text { development team of } \\
\text { Mediface }\end{array}$ & S.W. Choi & $\begin{array}{l}\text { Medical information } \\
\text { cloud platform }\end{array}$ \\
\hline 4 & Bionet Co. LTD. & 1999 & $\begin{array}{l}\text { Division spin-off } \\
\text { company (a) } 40.0 \% \text { stake } \\
\text { in the business in } 2000\end{array}$ & D.J. Gang & $\begin{array}{l}\text { Patient monitoring } \\
\text { system, } \\
\text { electrocardiograph, } \\
\text { respirometer, disposable } \\
\text { drug infuser, electrode }\end{array}$ \\
\hline 5 & Medical Standard & 2000 & $\begin{array}{l}\text { Medison investment } \\
\text { company (a) }\end{array}$ & $\begin{array}{l}\text { S.M. Lee and } \\
\text { H.Y. Hwang }\end{array}$ & $\begin{array}{l}\text { Picture Archiving and } \\
\text { Communications System }\end{array}$ \\
\hline 6 & M2 Community & 2011 & $\begin{array}{l}\text { Spin-off from the online } \\
\text { sector of M2Comm (a) }\end{array}$ & D.S. Han & $\begin{array}{c}\text { Soft ware (SW) } \\
\text { development }\end{array}$ \\
\hline 7 & Innoen Co. Ltd. & 2011 & $\begin{array}{l}\text { Spin-off from the } \\
\text { marketing division of } \\
\text { M2Comm (a) }\end{array}$ & B.I. Cho & $\begin{array}{l}\text { Medical marketing } \\
\text { agency, advertisements }\end{array}$ \\
\hline 8 & Iaanmed Co. Ltd. & 2005 & $\begin{array}{l}\text { Spin-off from UBCare Co. } \\
\text { Ltd. (a) }\end{array}$ & B.C. Kim & $\begin{array}{l}\text { Medical soft ware (SW) } \\
\text { management and } \\
\text { maintenance }\end{array}$ \\
\hline 9 & Intermed Co. Ltd. & 2003 & $\begin{array}{l}\text { Start-up from a spin-off } \\
\text { company (a) }\end{array}$ & M.H. Gang, & $\begin{array}{l}\text { Electroencephalography } \\
\text { (EEG) monitoring }\end{array}$ \\
\hline 10 & U2Bio & 2009 & $\begin{array}{l}\text { CEO of UBCare, a } \\
\text { spin-off company (a) }\end{array}$ & J.T. Kim & $\begin{array}{l}\text { Health Wallet, } \\
\text { information technology } \\
\text { (IT) based molecular } \\
\text { diagnosis check }\end{array}$ \\
\hline 11 & $\begin{array}{l}\text { M2Comm } \\
\text { (renamed from } \\
\text { M2Community) }\end{array}$ & 2002 & $\begin{array}{l}\text { The marketing } \\
\text { department of Medison } \\
\text { was spun off; } 50 \% \text { stake } \\
\text { in the business in } 2000 .\end{array}$ & B.I. Cho & $\begin{array}{l}\text { Medical marketing } \\
\text { agency, mobile business, } \\
\text { various solutions }\end{array}$ \\
\hline
\end{tabular}

Source: in-depth interview results; internal material of the Korea Creative Economy Research Network; Lee (2016).

Bolded firms and CEOs were interviewed by our research team directly.

Four examples from our intensive interviews (in Figure 2), after being employees of Medison and experiencing being a CEO of the open innovation channels of Medison, started their own start-ups. Thus, we call them open innovation serial entrepreneurs. Out of 11 open innovation serial entrepreneurs, 8 entrepreneurs were from spin-out open innovations. Spin-off entrepreneurs had more opportunities to experience all areas of new start-ups. According to the interview with J.T. Kim, who is the CEO of U2Bio, spin-offs allowed their employees to have more opportunities to become serial entrepreneurs compared to venture investments of external open innovation or joint ventures of coupled open innovation, although these partially offer opportunities to gain experience with start-ups. Therefore, the experience of a spin-off start-up is similar to venture incubation and provides more powerful motivation to the founding CEO to initiate a start-up, according to the interview with J.T. Kim. 


\section{Employee of Medison}

CEO et al. of Medison Open Innovation Channels

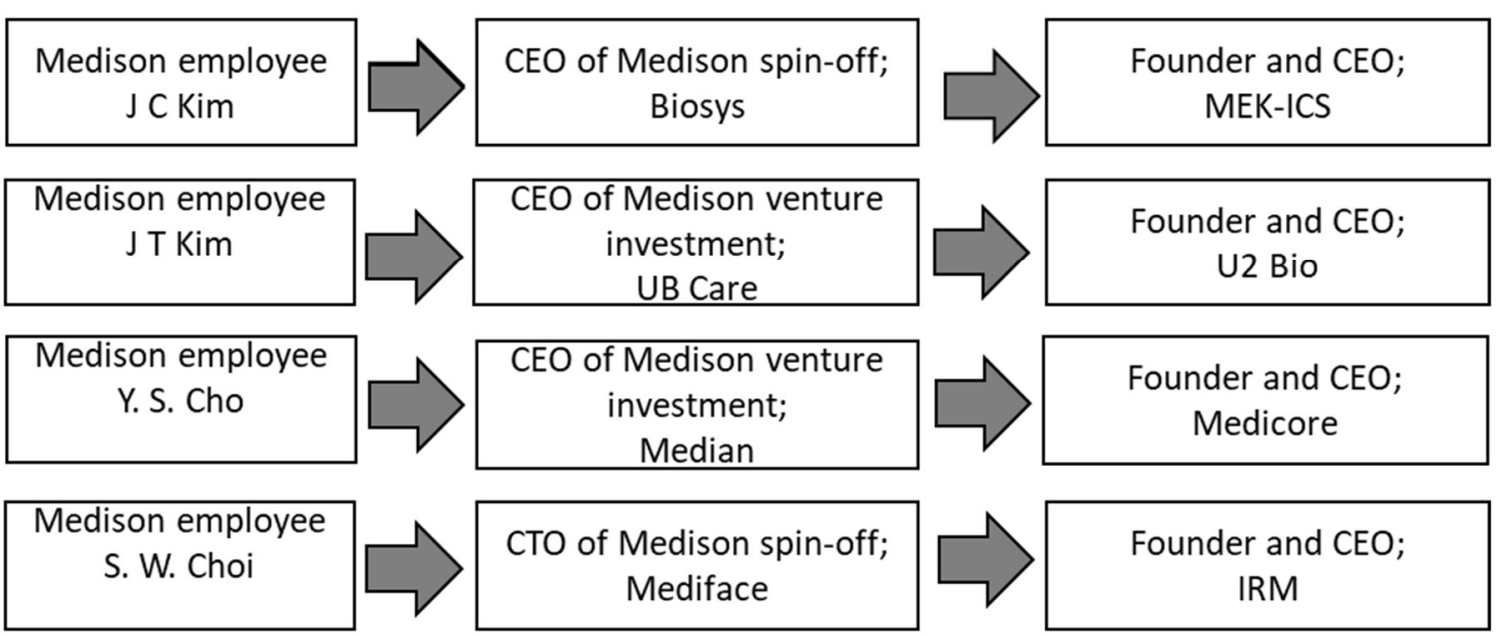

Figure 2. The structure of an open innovation serial entrepreneur (four cases).

J.T. Kim, who is the founding CEO of U2Bio (Table 1), had experience in the first Medison spin-off start-up UBCare (Appendix C), with the financial support, sales network, and brand of Medison. He became an executive of SK Group-UBCare and started a new business after his retirement. He stated that he learned many things at Medison and that he therefore decided to found U2Bio as a new challenge after resigning from his post. In particular, the experience in founding a company through open innovation actively provided motivation for his new business, and he explored a new area of business based on the medical data.

SeongWook Choi, the CEO of IRM (Table 1), worked at Medison and joined in founding a spin-off company called Mediface (Appendix E) as CTO at the age of 29. He noted that the internal corporate venture training and open innovation culture of Medison, as well as the experience of founding companies through an open innovation channel spin-off in his 20s, naturally led to the foundation of his own company. During our interview meeting, he continuously referred to Medison's weekly meetings, quarterly workshops, and management strategy meetings and how these events allowed members to naturally take ownership of the internal corporate venture and start-up culture. IRM creates medical data cloud platforms. Choi learned the innovation culture of openness and sharing as a member of Medison and developed it at his company.

ByeongIl Cho, the founding CEO of M2Comm (Table 1), who was the CEO of a spin-off from the marketing functional department of Medison M2Comm (Appendix C), extended his experience from the strong internal corporate venture culture of Medison to his founding of a start-up through an open innovation channel spin-off. Medison's internal corporate venture fostering program inspired his spin-out and new start-up strategies. He enabled DongSeok Han, who led the same sector by separating M2Community as a spin-out company from the software development department of M2Comm, to upgrade the company to the next level. Cho said that he aggressively expanded the medical marketing sector and founded Innoen, becoming its CEO by separating Innoen from M2Comm, but that he would appoint a person who led within the same field as its executive in the near future to further advance the company. Cho's strategy of serially founding spin-out companies of M2Comm involved implementing the goals of the spin-outs of functional departments and the strategies of expanding and deepening the business of Medison, according to our interview with him.

JongCheol Kim, who is the founding CEO of MEK-ICS (Table 1), worked at Medison and was then hired as the chief of the technology team at Biosys (Appendix E), a joint venture investment company of Medison. He had experience in all processes from the establishment of the company to product development and sales. With his experience in designing patient monitoring systems at 
Biosys, he received investment funding from Sein Electronics, a joint venture investor of Biosys, and developed a product that competes with Biosys. Kim also noted at the interview that his experiences of the Medison culture of encouraging the foundation of internal corporate ventures for three years, his participation in the establishment of a start-up through an open innovation channel-joint venture, and the development of products provided the decisive motivation for him to attempt to start a new business. Kim stated that the challenging spirit at MEK-ICS was based on the experience of entering new technology fields via the open innovation strategy of Medison and his experience at the joint venture firm.

As shown in Table 1, eight open innovation serial entrepreneurs were spin-offs from Medison, and three other entrepreneurs, including the MEK-ICS CEO, were from joint ventures and venture investments from Medison. According to interviews with 6 out of the 11 CEOs who were bolded (the same as the firm title), all were motivated through the Medison internal entrepreneurship culture and learned the process and how to start up a company due to their open innovation channel experience.

\section{Direct Serial Entrepreneurs}

Professor MinHwa Lee, founder of Medison, the Korea Venture Business Association, the Eurasian Network, and the Korea Creative Economy Research Network (Table 2), stated at the interview meeting that the internal corporate venture activation culture of Medison was an unavoidable choice to compete with global companies such as GE, Siemens, and Toshiba. He thought that the only way for Medison to survive in the global market, considering its size and capabilities, was to make each employee at Medison an entrepreneur. If the core business begins to flag, corporate entrepreneurship offers a solution with potential [63]. Lee noted that Medison selected a model similar to that of Google from the four corporate entrepreneurship models: the enabler, the producer, the opportunist, and the advocate. Hence, Medison provided enough funding and senior executive attention to prospective projects. Medison formed internal business development teams within its organization-internal corporate ventures-as much as possible in functional departments such as sales, production, promotion, financial management, and planning control, as well as in productional departments, such as the X-ray and MRI divisions. The basic spirit of the internal corporate venture system of Medison was to form a company within a company and encourage a reliable function or production team to be entrepreneurial and develop the self-interest that may be generated through high competition among the subteams of Medison, according to the interviews with M.S. Go, M.J. Gil, and M.H. Lee. 
Table 2. Medison's direct serial entrepreneur list.

\begin{tabular}{|c|c|c|c|c|}
\hline No. & Firm & Year founded & $\begin{array}{l}\text { Founder and } \\
\text { Others }\end{array}$ & $\begin{array}{c}\text { Business Field, Relationship with } \\
\text { Medison }\end{array}$ \\
\hline 1 & Medical Supply & 1989 & G.M. Kim & $\begin{array}{l}\text { Medical supply chain management } \\
\text { sister company, } \\
\text { initial member of Medison }\end{array}$ \\
\hline 2 & Mediana Medinus Co. Ltd. & 1993 & M.J. Gil & $\begin{array}{c}\text { Patient monitor, vital sign monitors, } \\
\text { AED worked on the overseas sales } \\
\text { team of Medison }\end{array}$ \\
\hline 3 & Unitek Co. Ltd. & 1994 & Y.J. You & $\begin{array}{l}\text { Disc decompression systems, worked } \\
\text { on the overseas sales team of Medison }\end{array}$ \\
\hline 4 & Mega Medical & 1995 & B.C. Kim & $\begin{array}{l}\text { Entertainment units, obesity } \\
\text { treatments, worked in marketing at } \\
\text { Medison for six years }\end{array}$ \\
\hline 5 & $\begin{array}{c}\text { Inbus (renamed from Korea } \\
\text { ERP Systems) }\end{array}$ & 1998 & B.Y. Ahn & $\begin{array}{c}\text { System software (SW) development } \\
\text { and distribution }\end{array}$ \\
\hline 6 & CU Medical Systems, Inc. & 2001 & $\begin{array}{l}\text { H.R. Na; a listed } \\
\text { company }\end{array}$ & $\begin{array}{l}\text { Automated external defibrillator, } \\
\text { external defibrillator }\end{array}$ \\
\hline 7 & Bistos & 2001 & H.J. Lee & $\begin{array}{l}\text { Fetal monitor, incubator, fetal } \\
\text { Doppler, phototherapy }\end{array}$ \\
\hline 8 & Gru I\&I & 2002 & M.S. Go & $\begin{array}{l}\text { Venture investment company, worked } \\
\text { on the planning team of Medison }\end{array}$ \\
\hline 9 & Genoray Co. Ltd. & 2001 & $\begin{array}{l}\text { B.W. Park } \\
\text { S.C. Kim }\end{array}$ & $\begin{array}{c}\text { C-arm (an imaging scanner } \\
\text { intensifier), X-ray, X-ray division of } \\
\text { Medison }\end{array}$ \\
\hline 10 & Meditech & 2002 & B.H. Kim & $\begin{array}{c}\text { Medical device module, medical } \\
\text { device keyboard }\end{array}$ \\
\hline 11 & Hubidic Co. Ltd. & 2002 & J.H. Shin & $\begin{array}{l}\text { Thermometer, blood pressure } \\
\text { measuring devices, low-frequency } \\
\text { stimulator }\end{array}$ \\
\hline 12 & Bionics Co. Ltd. & 2004 & D.S. Kim & $\begin{array}{l}\text { Patient monitoring system, fetal hear } \\
\text { rate monitoring system, } \\
\text { electrocardiograph }\end{array}$ \\
\hline 13 & $\begin{array}{c}\text { UTB Co. Ltd. } \\
\text { (renamed Sono Solution) }\end{array}$ & 2004 & Y.J. Cho & $\begin{array}{l}\text { Ultrasound diagnostic units for } \\
\text { medical use, worked at Medison }\end{array}$ \\
\hline 14 & $\begin{array}{l}\text { Korea Venture Business } \\
\text { Association }\end{array}$ & 1995 & $\begin{array}{l}\text { M.H. Lee and J. } \\
\text { Jeong }\end{array}$ & Support of ventures \\
\hline 15 & Biosoundlab & 2007 & $\begin{array}{l}\text { C.J. Park and S.W. } \\
\text { Lee (Medison) }\end{array}$ & Hearing aids \\
\hline 16 & Votem & 2007 & $\begin{array}{l}\text { M.S. Gang, S.S. } \\
\text { Park (Medison) }\end{array}$ & Patient monitors and pulse oximeter \\
\hline 17 & Mediconet & 2008 & Y.D. Han & $\begin{array}{l}\text { Hyperbaric oxygen therapy, cameras } \\
\text { for medical use }\end{array}$ \\
\hline 18 & Eurasian Network & 2008 & M.H. Lee & $\begin{array}{l}\text { Publication and academic project, } \\
\text { founder and former CEO of Medison }\end{array}$ \\
\hline 19 & Smart care works Co. Ltd. & 2010 & J.B. Cheon & SW packages for medical use \\
\hline
\end{tabular}


Table 2. Cont.

\begin{tabular}{|c|c|c|c|c|}
\hline No. & Firm & Year founded & $\begin{array}{l}\text { Founder and } \\
\text { Others }\end{array}$ & $\begin{array}{c}\text { Business Field, Relationship with } \\
\text { Medison }\end{array}$ \\
\hline 20 & Waygence Co. Ltd. & 2011 & $\begin{array}{l}\text { C.J. Park and D.A. } \\
\text { You (Medison) }\end{array}$ & $\begin{array}{c}\text { Exploring new markers through the } \\
\text { technical convergence of medical } \\
\text { devices }\end{array}$ \\
\hline 21 & $\begin{array}{l}\text { Korea Creative Economy } \\
\text { Research Network }\end{array}$ & 2013 & M.H. Lee & $\begin{array}{l}\text { Academic projects for medical } \\
\text { management research project } \\
\text { collaboration with governmental } \\
\text { agencies, founder and former CEO of } \\
\text { Medison }\end{array}$ \\
\hline 22 & Han Sono & 2015 & $\begin{array}{l}\text { S.B. Gye and Y.B. } \\
\text { Lee (Medison) }\end{array}$ & Digital stimulator for medical use \\
\hline 23 & $\begin{array}{l}\text { Healthpia (no longer } \\
\text { operating) }\end{array}$ & 2004 & K.S. Lee & $\begin{array}{l}\text { Blood sugar measurements and } \\
\text { glycosuria information management } \\
\text { instrument; M.H. Lee joined as a } \\
\text { technology consultant }\end{array}$ \\
\hline
\end{tabular}

Source: in-depth interview results; internal material from the Korea Creative Economy Research Network; Lee (2016). Bolded firms and CEOs were interviewed by our research team directly.

One of the characteristics of the internal corporate venture system at Medison is that the company fully embraces failure. The acceptance of failure allows for potential entrepreneurship, as employees think about internal ventures or starting their own start-up, according to M.J. Gil and M.S. Go. Lee strongly expressed willingness to accept and embrace new attempts and failures through internal corporate ventures. Executive engagement is essential for employees to trust that the process of corporate entrepreneurship is being taken seriously and that good ideas will indeed be developed and commercialized [63]. Another characteristic of the internal venture system at Medison is that internal ventures have the opportunity to indirectly experience start-ups via the open innovation channels of Medison, such as spin-outs, joint-ventures, and venture investments (M.J. Gil and M.S. Go).

Many employees of Medison (and the CEO of Medison) who experienced the role of leaders at intraventures started their own start-ups. Thus, we call them the (pseudo)direct serial entrepreneurs of Medison (Figure 3).

Among 23 direct serial entrepreneurs, 18 direct entrepreneurs began after 2000 (Table 2). This means that most of the direct serial entrepreneurs had the opportunity to learn indirectly from the open innovation channels of Medison.

MinHwa Lee founded the Korea Venture Business Association while socially extending the internal corporate venture system and the federal system of ventures at Medison, leading to the activation of the Korean venture ecosystem (Table 2). He also established the Korea Creative Economy Research Network (Table 2), which focused on consulting and starting projects to spread the openness and sharing culture of open innovation.

MoonJeong Gil, CEO of Mediana, worked as part of the overseas sales team at Medison for three years and was on the internal importation venture team of Medison, Meditech, for half a year. After this, he set up his own medicine instrument importing firm, Mediana (Table 2), without funding from Medison, despite Medison wanting to fund his start-up. He was highly motivated by the internal venture culture and the possibility of using the workforce and marketing network at Medison, according to the interview. Although conflicts of interests between Medison and Mediana were possible, even though the resources at Medison were used, no funding was received from Medison. 


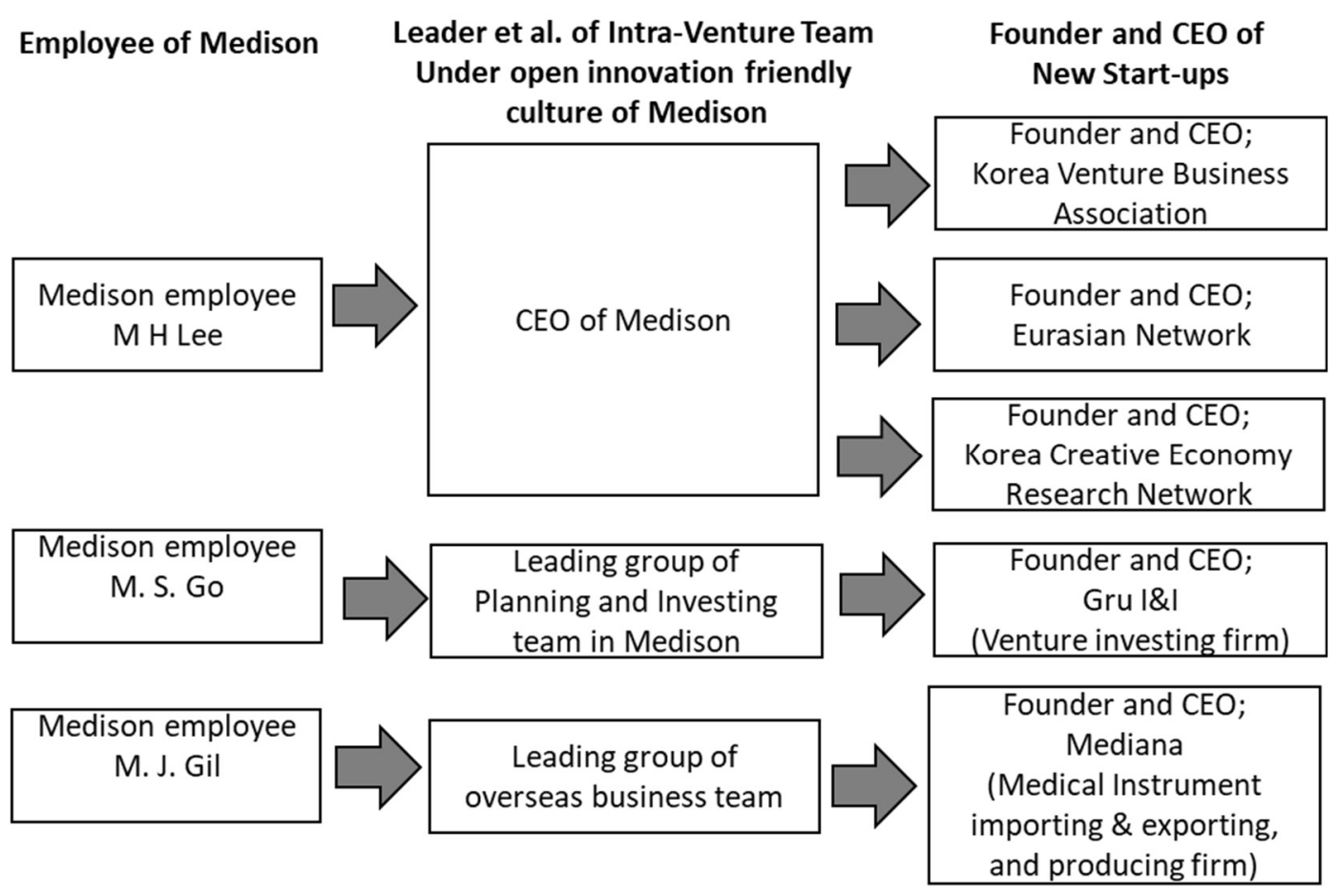

Figure 3. The structure of the direct serial entrepreneur (five cases).

Thus, MoonJeong Gil identified the current conditions of the global IT medical device sector while engaged in overseas sales and founded a company based on his knowledge of the market. In addition, the sales network at Medison assisted his business through its early stages of growth. The experiences of the internal corporate venture culture at Medison and the internal venture of the overseas sales team, Meditech (at Medison), encouraged Gil to start a company. His experience at Medison was the driving force for open innovation-based technology accumulation and product development, such as the technology accumulated through the import, sales, and repair of overseas medical devices as well as official development assistance (ODA), R\&D and product development, and related business diversification efforts.

ManSeok Go, who founded Gru I\&I (Table 2), helped MinHwa Lee, the founder of Medison, to create a venture investment and a joint venture while he was working as part of the planning team at Medison. With his experience at Medison, he operated a venture investment company for 15 years. He noted at the interview that his experience of focusing on three sectors (medical, biology, and IT fields), creating mutual synergy, and implementing the transcendental-live firm strategy at Medison were the sources of his venture investment project. He continuously mentioned that the motivating strategy of Medison to let each member engage in independent entrepreneurship attracted him to join Medison after leaving a stock company. He maintains his main businesses based on investments, networks, and consulting for the companies invested by Medison, as led by its founder, according to our interview.

There are several Medison-based companies, as identified through the interviews and a literature review by the research team. As shown in Table 2, there was 1 firm in the 1980s, 5 in the 1990s, 12 in the 2000s, and 4 in the 2010s. A separate study noted that nearly 50 companies were direct serial entrepreneur firms of Medison. Between 2003 and 2010, the policies of intraventure and foundation through open innovation led by MinHwa Lee, founder of Medison, operated as a platform for start-ups. The Medison Mafia founders, who are direct serial entrepreneurs as well as open innovation serial entrepreneurs from Medison, unanimously spoke with one voice that stated that more than 100 serial entrepreneurs had been created from Medison from a total of only 300 employees due to the direct 
and indirect experience gained in its start-up training culture and open innovation channel start-ups, in addition to the internal corporate venture system.

\section{Conclusions}

\subsection{Findings}

First, an open innovation strategy can be a strong motivator for serial entrepreneurs. According to our research, open innovation has two ways of creating serial entrepreneur motivation effects such as those shown in Figure 4. Motivation-1 in Figure 4 illustrates that employees at Medison experienced start-ups by seeing and communicating with firms from spin-offs, venture investments, and joint ventures of Medison in addition to experiencing the intraventure of an open innovation-friendly culture started new start-ups as direct serial entrepreneur (M.H. Lee, M.S. Go, and M.J. Gil; Appendix B). Motivation-2 shows that the strong intraventure environment based on the open innovation-friendly culture motivated the CEO, CTO or et al. who already had experience of starting start-ups from open innovation channels to set up new start-ups as open innovation serial entrepreneurs (J.C. Kim, J.T. Kim, Y.S. Cho, S.W. Choi, and B.I. Cho; Appendix B). An open innovation-friendly culture not only provides the motivation to start open innovation channel start-ups but also provides the motivation to create open innovation serial entrepreneurs. That is to say, an open innovation strategy can be a strong motivator for serial entrepreneurs.

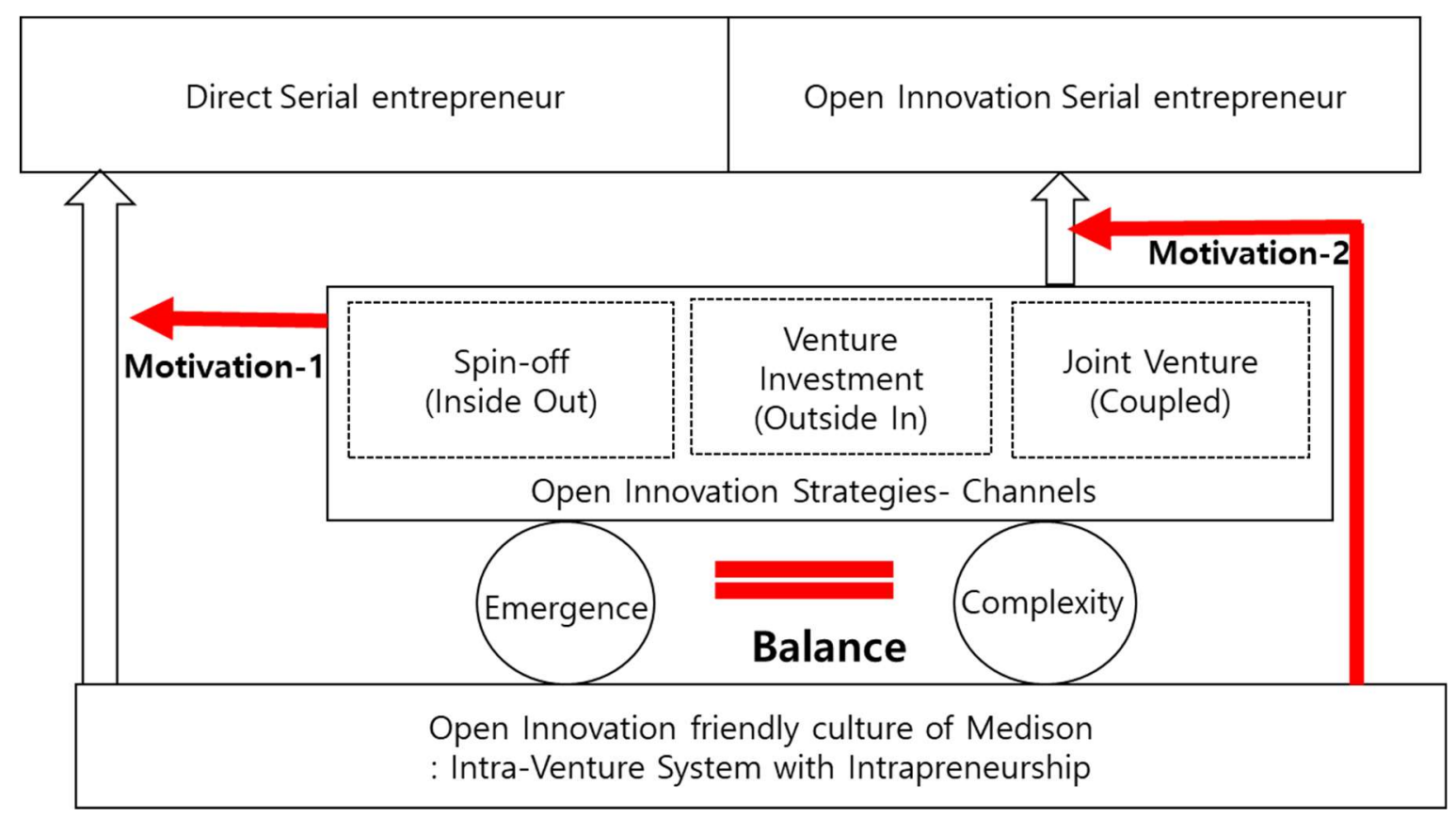

Figure 4. Motivation and the balance between emergence and complexity through open innovation.

Second, a balance between emergence and complexity is required to trigger sustainable serial entrepreneurs of open innovation. A balance between emergence, which is motivated by open innovation, and complexity, which occurs through open innovation, is required for the sustainability of firms and the open innovation ecosystem (J.C. Kim, J.T. Kim, Y.S. Cho, S.W. Choi, and M.J. Gil; Appendix B). Open innovation leads to the emergence of creative business models or new successful businesses only after some degree of complexity is controlled [55]. Even though open innovation is a strong force for driving the emergence of creative business models and new companies, it also creates complexity, in other words, the "more is not always better effect" [55,64-67]. If emergence and complexity are not balanced, open innovation channels cannot be maintained. All serial entrepreneurs 
can be affected by the sequence of the collapse of open innovation start-ups, as shown by the situation of emergence and complexity in Figure 4.

In the case of Medison, strong open innovation led to multiple complexities, such as those illustrated in Figure 5 With the causal relations that were found in this study between serial entrepreneurship, open innovation channels, emergence by open innovation, complexity by open innovation, and performance, in addition to the institutionalization of an open innovation culture, Medison's causal model for open innovation with emergence and complexity was built like that shown in Figure 5 and Appendix F, with seven reinforcing loops and three balancing loops (Appendix F). We did not validate this model, as this causal loop model did not add additional factors that were not studied in this study and did not try to capture additional findings [68]. Even though the system dynamic causal loop has several weaknesses, such as validations and simulations, it is useful as a mental model to discover the systemic implication of any strategy results $[69,70]$. In this causal loop model, complexity by open innovation only negatively affects the firm's performance.

First, the overlapping business areas between open innovation channel start-ups caused conflicts. Collisions and excessive competition due to the overlapping business areas emerged more as the number of serial entrepreneurs increased. As a result, conflicts arose between several start-ups related to the balancing loop B-ch1, which is explained in Appendix F. Second, feedback to the functional and business departments of Medison was lacking regarding the profits generated by various serial entrepreneurs. In particular, as the profits generated by the open innovation channel companies were low, Medison alone supported them. In addition, systems were not established for feedback about the serial firms' profits in the context of the profits of Medison. This was related to the balancing loop B-SE1, which is also explained in Appendix F. Third, the so-called brain-drain from Medison to the spin-offs had serious negative effects on Medison. Fourth, for some time, significant competitive issues existed between Medison and its spin-offs. Fifth, many potential growth areas were intercepted by the spin-offs, and these had long-lasting negative effects on Medison. The third, fourth, and fifth issues noted here are related to balancing loop B-Cu1 (Appendix F).

Thus, as Medison lost control of the complexities in open innovation, despite the combined effects of the open innovation-friendly culture and the two-sided feedback loops of the open platforms, the original company collapsed. In the 2000s, the enterprise value of Medison was USD \$900 million, whereas that of the Medison family firms was USD \$2.3 billion. However, in late 2015, the value of Medison was USD $\$ 800$ million and that of the Medison family firms USD $\$ 7.2$ billion. These figures show that during the receivership of Medison in 2003, there was no systematic process controlling the level of open innovation complexity in the national innovation system of Korea [71]. 


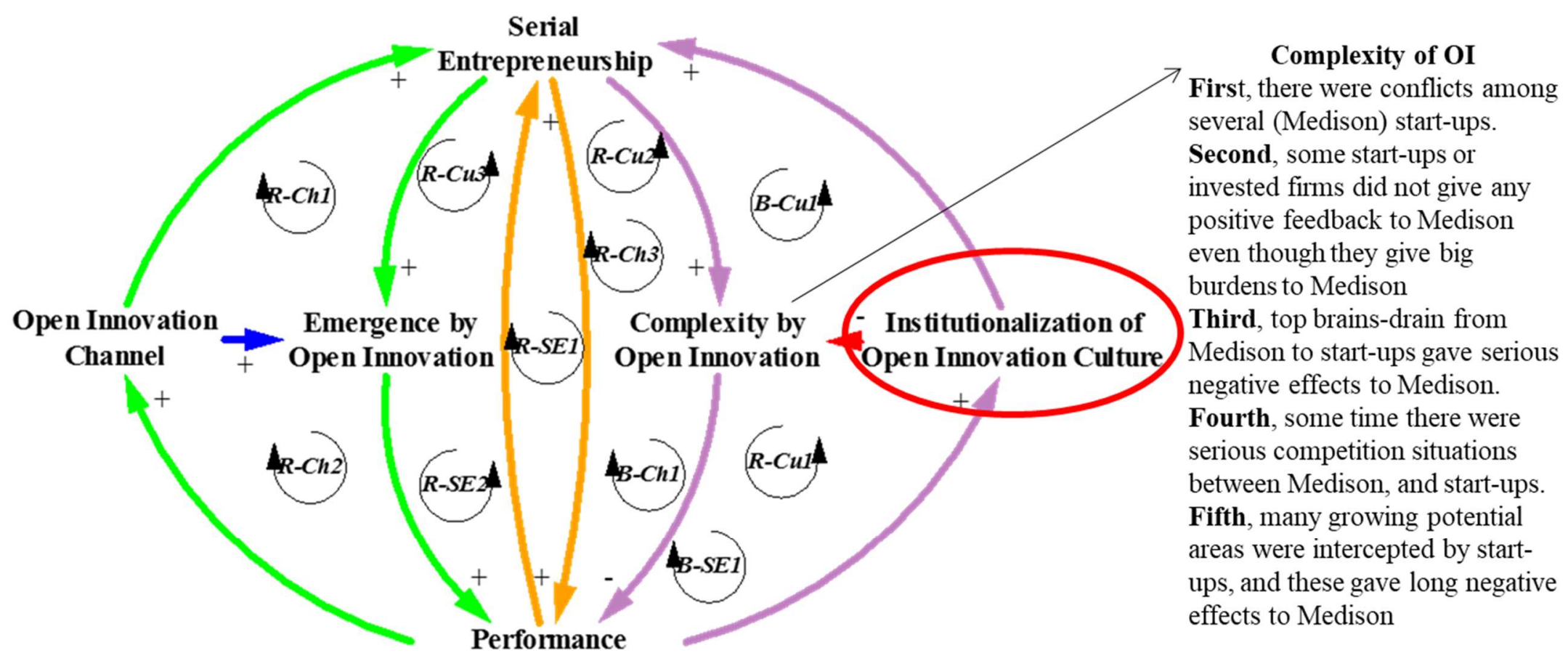

(Revenue, Profit, etc)

Figure 5. Medison's causal model for open innovation with emergence and complexity. 


\subsection{Implications}

The theoretical implication of these findings is that we discovered a method of sustainable open innovation. First, open innovation can act as a platform for serial entrepreneurship by providing the experience of becoming an entrepreneur though open innovation channels such as spin-outs, joint ventures, or venture investments. Based on these open innovation channels, different serial entrepreneurs can be motivated. Second, open innovation motivates not only the emergence of new opportunities, such as new business models, new technologies, or new markets, but also increases complexity, which can destroy the firm. Therefore, when choosing an open innovation strategy, the means by which to control the complexity that will arise from open innovation should also be considered. The diverse complexities that appear with the increase of open innovation should be controlled.

The practical implication of this study is to find a system through which to create sustainable serial entrepreneurs. First, governments should consider not only start-up motivation policies but also open innovation serial entrepreneur motivation policies through collaboration with firms if they want to create new jobs and industries. Open innovation is a strategy that can be chosen by firms to obtain a new business model and can also be a useful policy agenda for governments to tackle the creation of jobs and industries. Second, firms should maintain a balance between the emergence of open innovation and the complexity that it causes. Even though the emergence potential of an open innovation strategy is considerable, the company can collapse if it is not able to control the open innovation complexity.

\subsection{Limitations and Future Research Agenda}

We used a case study with a deep interview method. Therefore, there are limits to the research results. Additional case studies and statistical research are required to overcome the limits of the generation problem in this study.

Second, the different effects of motivating serial entrepreneurs according to open innovation channels should be further researched. Depending on the sector and environment, open innovation channels such as spin-outs, joint-ventures, and venture investments will motivate different start-ups. Therefore, the different effects on open innovation channels in serial entrepreneurship and the conditions that determine the serial entrepreneurship of open innovation channels will be the focus of our future research agenda.

Third, the conditions and processes of successfully introducing an intraventure environment within the cultural context of open innovation must be studied in depth. Additional case studies should be conducted on companies with intraventure environments or an open innovation-friendly culture.

Fourth, the relationship between open innovation channels and the design of intraventure environments should be researched, possibly through horizontal comparative case studies and statistical analyses. Fifth, it could be useful to conduct a bibliometric analysis concentrating on the subject of serial entrepreneurship from open innovation and to build a map showing the existing relationships between open innovation and serial entrepreneurs [72,73].

Author Contributions: J.H.J.Y. was responsible for conceptualization, formal analysis, and writing-original draft preparation. M.H.L. was responsible for interview arrangement, contents material searching, supervision, and validation of the research results. X.Z. and K.B.P. fully joined in all of the interviews of this research and analyzed the interview results with the first author.

Funding: This research received no external funding.

Acknowledgments: This work was supported by the DGIST R\&D Program of the Ministry of Science and ICT (19-IT-01), and additionally supported by the National Research Foundation of Korea Grant and funded by the Korean Government (NRF-2017S1A3A22066084).

Conflicts of Interest: The authors declare no conflict of interest. 


\section{Appendix A. Semistructured Questionnaire}

Part 1. An overview of the current (participating) company.

\begin{tabular}{|l|l|}
\hline \multirow{5}{*}{ The relationship with Medison } & $\begin{array}{l}\text { (a) Spin-off company: a company that grew up in the Medison } \\
\text { department or subsidiary }\end{array}$ \\
\cline { 2 - 3 } & $\begin{array}{l}\text { (b) Venture investment company: companies in which Medison invested } \\
\text { in the company's growth and process }\end{array}$ \\
\cline { 2 - 2 } & $\begin{array}{l}\text { (c) Joint venture company: venture companies created by Medison and } \\
\text { other partners }\end{array}$ \\
\hline & (d) CEO was from a, b, or c (including the core entrepreneurial groups) \\
\hline & (e) CEO came from Medison (including the core entrepreneurial groups) \\
\hline (f) Others \\
\hline
\end{tabular}

Part 2. The relationship between your company and Medison.

(1) Medison had meaning in the foundation of our company.

\begin{tabular}{|c|c|c|c|c|}
\hline $\begin{array}{c}\text { 1) Almost } \\
\text { Meaningless }\end{array}$ & 2) A Little Meaning & 3) Meaningful & $\begin{array}{l}\text { 4) Important } \\
\text { Meaning }\end{array}$ & $\begin{array}{l}\text { 5) Greatest } \\
\text { Meaning }\end{array}$ \\
\hline $\begin{array}{l}\text { Please expla } \\
< \\
\text { (2) Medisor }\end{array}$ & $\begin{array}{l}\text { he reason: } \\
\text { s meaningful in the }\end{array}$ & owth of our cor & $>$ & \\
\hline $\begin{array}{c}\text { 1) Almost } \\
\text { Meaningless }\end{array}$ & 2) A Little Meaning & 3) Meaningful & $\begin{array}{l}\text { 4) Important } \\
\text { Meaning }\end{array}$ & $\begin{array}{l}\text { 5) Greatest } \\
\text { Meaning }\end{array}$ \\
\hline
\end{tabular}

Part 3. The following questions are about Medison's open innovation strategy.

(1) Medison had a culture that promoted open innovation.

\begin{tabular}{ccccc}
\hline $\begin{array}{c}\text { 1) Almost did not } \\
\text { have an open }\end{array}$ & $\begin{array}{c}\text { 2) A little open } \\
\text { innovation culture }\end{array}$ & $\begin{array}{c}\text { 3) Had an open } \\
\text { innovation culture }\end{array}$ & $\begin{array}{c}\text { 4) A significant } \\
\text { open innovation } \\
\text { innovation culture }\end{array}$ & $\begin{array}{c}\text { 5) Very strong open } \\
\text { innovation culture }\end{array}$ \\
\hline
\end{tabular}

Please explain the reason:

$<$

(2) Medison had a strategy to promote open innovation.

\begin{tabular}{ccccc}
\hline 1) Almost did not & 2) Few open & 3) Had open & 4) Significant open & 5) Very strong open \\
have an open & innovation & innovation & innovation & innovation \\
innovation strategy & strategies & strategies & strategies & strategies \\
\hline
\end{tabular}

Please explain the reason:

$<$ 
(3) Medison had an organization that promoted open innovation.

\begin{tabular}{ccccc}
\hline $\begin{array}{c}\text { 1) Almost did not } \\
\text { have an open }\end{array}$ & $\begin{array}{c}\text { 2) Few open } \\
\text { innovation }\end{array}$ & $\begin{array}{c}\text { 3) Had open } \\
\text { innovation } \\
\text { innovation }\end{array}$ & $\begin{array}{c}\text { 4) Significant open } \\
\text { innovation }\end{array}$ & $\begin{array}{c}\text { 5) Very strong open } \\
\text { innovation }\end{array}$ \\
organization & organizations & organizations & organizations & organizations \\
\hline
\end{tabular}

Please explain the reason

(4) Medison used open innovation strategies that contributed to your own company development.

\begin{tabular}{lcccc}
\hline $\begin{array}{l}\text { 1) Almost no } \\
\text { contribution }\end{array}$ & $\begin{array}{c}\text { 2) A little } \\
\text { contribution }\end{array}$ & $\begin{array}{c}\text { 3) Had a } \\
\text { contribution }\end{array}$ & $\begin{array}{l}\text { 4) Important } \\
\text { contribution }\end{array}$ & $\begin{array}{c}\text { 5) Significant } \\
\text { contribution }\end{array}$ \\
\hline
\end{tabular}

Please explain the reason:

$<$

(5) Medison used open innovation strategies that conflicted with your company development.

\begin{tabular}{|c|c|c|c|c|}
\hline $\begin{array}{l}\text { 1) Almost no } \\
\text { conflict }\end{array}$ & 2) Little conflict & 3) Conflict & $\begin{array}{l}\text { 4) Important } \\
\text { conflict }\end{array}$ & $\begin{array}{l}\text { 5) Significant } \\
\text { conflict }\end{array}$ \\
\hline
\end{tabular}

Please explain the reason:

$<$

Part 4. This is about your company's open innovation strategy.

(1) Our company has a culture that promotes open innovation.

\begin{tabular}{ccccc}
\hline $\begin{array}{c}\text { 1) Almost does not } \\
\text { have an open }\end{array}$ & $\begin{array}{c}\text { 2) A little open } \\
\text { innovation culture }\end{array}$ & $\begin{array}{c}\text { 3) Has an open } \\
\text { innovation culture }\end{array}$ & $\begin{array}{c}\text { 4) A significant } \\
\text { open innovation } \\
\text { innovation culture }\end{array}$ & $\begin{array}{c}\text { 5) Very strong open } \\
\text { innovation culture }\end{array}$ \\
\hline
\end{tabular}

Please explain the reason:

$<$

(2) Our company has a strategy to promote open innovation.

\begin{tabular}{ccccc}
\hline 1) Almost does not & 2) Few open & 3) Has open & 4) Significant open & 5) Very strong open \\
have an open & innovation & innovation & innovation & innovation \\
innovation strategy & strategies & strategies & strategies & strategies \\
\hline
\end{tabular}

Please explain the reason:

$<$ 
(3) Our company has an organization that promotes open innovation.

\begin{tabular}{|c|c|c|c|c|}
\hline $\begin{array}{l}\text { 1) Almost does not } \\
\text { have an open } \\
\text { innovation } \\
\text { organization }\end{array}$ & $\begin{array}{l}\text { 2) Few open } \\
\text { innovation } \\
\text { organizations }\end{array}$ & $\begin{array}{l}\text { 3) Has open } \\
\text { innovation } \\
\text { organizations }\end{array}$ & $\begin{array}{l}\text { 4) Significant open } \\
\text { innovation } \\
\text { organizations }\end{array}$ & $\begin{array}{l}\text { 5) Very strong open } \\
\text { innovation } \\
\text { organizations }\end{array}$ \\
\hline
\end{tabular}

Please explain the reason:

$<$

(4) Our company has a future plan to promote open innovation.

\begin{tabular}{lllll}
\hline $\begin{array}{l}\text { 1) Almost does not } \\
\text { have a future plan }\end{array}$ & 2) Few future plans & 3) Has a future plan & $\begin{array}{l}\text { 4) Significant } \\
\text { future plans }\end{array}$ & $\begin{array}{c}\text { 5) Very strong } \\
\text { future plans }\end{array}$ \\
\hline
\end{tabular}

Please explain the reason:

$<$ 


\section{Appendix B.}

Table A1. In-depth interviewee list with main contents.

\begin{tabular}{|c|c|c|c|c|}
\hline Date and Interviewee & Present Affiliation & Main Products & Relationship with Medison & Main Contents of Interviews \\
\hline $\begin{array}{c}15 \text { November } 2016 \\
\text { M.H. Lee }\end{array}$ & $\begin{array}{l}\text { CEO of Korea Creative } \\
\text { Economy Network, } \\
\text { Eurasian Network }\end{array}$ & $\begin{array}{l}\text { Start-up, venture consulting, } \\
\text { social networking with } \\
\text { history perspective }\end{array}$ & Former CEO of Medison & $\begin{array}{l}\text { - Category: direct serial entrepreneur } \\
\text { - Expand Medison role as open innovation platform to Korea } \\
\text { economy } \\
\text { - Free intraventure and failure acceptance open innovation culture } \\
\text { at Medison } \\
\text { - Medison was open platform for Korean medical equipment firms }\end{array}$ \\
\hline $\begin{array}{l}6 \text { December } 2016 \\
\text { J.C. Kim }\end{array}$ & CEO of MEK-ICS & $\begin{array}{l}\text { Intensive care unit (ICU) } \\
\text { monitoring systems, } \\
\text { respirators }\end{array}$ & $\begin{array}{l}\text { Worked at Medison, CTO of } \\
\text { Biosis, a spin-off of Medison, }\end{array}$ & $\begin{array}{l}\text { - Category: open innovation (joint venture) serial entrepreneur } \\
\text { (Table 1) } \\
\text { - Let employee move to owner through stock option } \\
\text { - From Medison to joint venture Biosys and set up patient } \\
\text { monitoring system start-up Mek-ICS } \\
\text { - Tries to increase the workforce of Mek-ICS as in Medison by } \\
\text { sharing open innovation culture, but it is not easy }\end{array}$ \\
\hline $\begin{array}{l}11 \text { July } 2017 \\
\text { J.T. Kim }\end{array}$ & CEO of U2Bio & $\begin{array}{l}\text { Medical examination SW, } \\
\text { medical examination kits }\end{array}$ & $\begin{array}{c}\text { At a start-up. Worked at } \\
\text { Medison, CEO of UBCare, a } \\
\text { venture investment company } \\
\text { of Medison }\end{array}$ & $\begin{array}{l}\text { - Category: open innovation (spin-off) serial entrepreneur, Table } 1 \\
\text { - Medison let us create a spin-off after three years of working and } \\
\text { supported us in workforce and finance } \\
\text { - Full experience as CEO at UBcare (Appendix C) let me choose } \\
\text { new start-up easily because of accumulated experience of } \\
\text { management in addition to technology } \\
\text { - Organizing in U2Bio venture ecosystem to let all employees have } \\
\text { a chance to start new firm }\end{array}$ \\
\hline $\begin{array}{l}14 \text { August } 2017 \\
\text { Y.S. Cho }\end{array}$ & CEO of Medicore & $\begin{array}{c}\text { Medical infrared } \\
\text { thermograph systems, } \\
\text { autonomic nerve analyzers, } \\
\text { stress measuring systems }\end{array}$ & $\begin{array}{l}\text { A start-up CEO of Median, a } \\
\text { venture investment company } \\
\text { of Medison }\end{array}$ & $\begin{array}{l}\text { - Category: open innovation (spin-off) serial entrepreneur, } \\
\text { Table A2 and venture investment by Medison } \\
\text { - Meridian (Appendix C) CEO experience let him start new } \\
\text { start-up with venture investment by Medison in addition to the } \\
\text { transfer of blood diagnosis technology from Medison } \\
\text { - Medison let all departments be managed independently }\end{array}$ \\
\hline
\end{tabular}


Table A1. Cont.

\begin{tabular}{|c|c|c|c|c|}
\hline Date and Interviewee & Present Affiliation & Main Products & Relationship with Medison & Main Contents of Interviews \\
\hline $\begin{array}{l}18 \text { August } 2017 \\
\text { S.W. Choi }\end{array}$ & IRM & $\begin{array}{l}\text { Medical information cloud } \\
\text { platform }\end{array}$ & $\begin{array}{l}\text { Worked at Medison, chief of } \\
\text { the development team of } \\
\text { Mediface, a spin-off of } \\
\text { Medison }\end{array}$ & $\begin{array}{l}\text { - Category: open innovation (spin-off) serial entrepreneur (Table 1) } \\
\text {-Medison and Mediface (Table A3) founding experience let him } \\
\text { start three more new start-ups until IRM } \\
\text { - All Mediface founding persons from Medison received partial } \\
\text { ownership } \\
\text { - At every weekly meeting, quarterly workshop, and management } \\
\text { strategy meeting, Medison culture or Medison spirit was } \\
\text { emphasized, which was a kind of entrepreneurship or open } \\
\text { innovation sprit }\end{array}$ \\
\hline $\begin{array}{l}22 \text { August } 2017 \\
\text { M.S. Go }\end{array}$ & Gru I\&I & $\begin{array}{l}\text { Medical service start-up } \\
\text { consultation, medical } \\
\text { service venture investment, } \\
\text { patient monitor, et al. }\end{array}$ & $\begin{array}{l}\text { Worked on the planning team } \\
\text { of Medison, a start-up }\end{array}$ & $\begin{array}{l}\text { - Category: direct serial entrepreneur (Table 2) } \\
\text { - Medison venture incubating department role was moved to set } \\
\text { up venture investment companies } \\
\text { - Now connecting Medison-related firms and investing in medical } \\
\text { venture that had relationships with Medison } \\
\text { - Medison invested in diverse and different areas with core of Bio + } \\
\text { IT such as Viromed, JVM, Muhan Investment, etc., with the image } \\
\text { of a future as CEO with support of planning team of Mr. Go }\end{array}$ \\
\hline $\begin{array}{l}22 \text { August } 2017 \\
\text { M.J. Gil }\end{array}$ & Mediana & $\begin{array}{l}\text { Patient monitor, vital sign } \\
\text { monitor, AED }\end{array}$ & $\begin{array}{l}\text { Worked on the overseas } \\
\text { business team of Medison, a } \\
\text { start-up }\end{array}$ & $\begin{array}{l}\text { - Category: direct serial entrepreneur (Table 2) } \\
\text { - From Intra Venture Meditech, which imported medical } \\
\text { instruments for Medison to start up Mediana } \\
\text { - Mediana developed a patient monitor, virtual sign monitors, etc., } \\
\text { through collaboration research, developing outsourcing, } \\
\text { manufacturing outsourcing, or diverse open innovation channels }\end{array}$ \\
\hline $\begin{array}{l}23 \text { August } 2017 \\
\text { B.I. Cho }\end{array}$ & M2Comm & $\begin{array}{l}\text { Marketing agency, mobile } \\
\text { business, development of } \\
\text { various solutions }\end{array}$ & $\begin{array}{l}\text { Worked at Medison, a spin-off } \\
\text { of the marketing team of } \\
\text { Medison }\end{array}$ & $\begin{array}{l}\text { - Category: open innovation (spin-off, Table 1), serial entrepreneur } \\
\text { - From Medison marketing team intraventure, which focused on } \\
\text { online marketing through spin-off M2Comm to independent } \\
\text { M2Comm } \\
\text { - Pursuing business diversification in medical instruments, } \\
\text { pressing, silver industry, warehouse, café industries, etc., in } \\
\text { addition to setting up three intraventure systems }\end{array}$ \\
\hline $\begin{array}{l}27 \text { October } 2017 \\
\text { Anonymous }\end{array}$ & $\begin{array}{l}\text { Health Medical } \\
\text { Equipment division }\end{array}$ & & $\begin{array}{l}\text { Worked at Medison, } \\
\text { worked at the Health Medical } \\
\text { Equipment division of } \\
\text { Samsung Medison }\end{array}$ & $\begin{array}{l}\text { - Category: Samsung Medison } \\
\text { - Medison was a platform firm for diverse Korean medical } \\
\text { instrument firms, including Medison federal firms } \\
\text { - There were conflicts between open innovation firms or serial } \\
\text { entrepreneur firms } \\
\text { - Open innovation culture of Medison developed all employees as } \\
\text { potential entrepreneurs }\end{array}$ \\
\hline
\end{tabular}


Appendix C.

Table A2. Medison's spin-off list.

\begin{tabular}{|c|c|c|c|c|c|}
\hline No. & Firms & Year Founded & Relationship with Medison & Founder and Others & Business Field \\
\hline 1 & UBCareCo. Ltd. & $\begin{array}{l}\text { Founded in 1992, } \\
\text { incorporated in } 1994\end{array}$ & $\begin{array}{l}\text { The picture archiving communications system (PACS) } \\
\text { development team that converted images from an } \\
\text { ultrasonic diagnosis system into digital files and } \\
\text { saved and processed them was spun off. } \\
\text { First internal corporate venture at Medison, } 39.8 \% \\
\text { stake in the business in } 2000 \text {. }\end{array}$ & $\begin{array}{l}\text { J.T. Kim and S.K. Lee; } \\
\text { listed company; a } \\
\text { subsidiary of SK Group }\end{array}$ & $\begin{array}{l}\text { System software, } \mathrm{U} \\
\text { healthcare, medical } \\
\text { information }\end{array}$ \\
\hline 2 & $\begin{array}{l}\text { Meridian Co. Ltd. } \\
\text { (renamed from Mediface) }\end{array}$ & 1994 & $\begin{array}{l}\text { The Dongseo medical device development team of the } \\
\text { Meridian system was spun off; } 53 \% \text { stake in the } \\
\text { business in } 1998 .\end{array}$ & $\begin{array}{l}\text { I.B. Park and H.H. } \\
\text { Myeong (Medison) }\end{array}$ & Pulse wave analyzer \\
\hline 3 & $\begin{array}{l}\text { MGB Endoscopy Co. Ltd. } \\
\text { (renamed from Welson } \\
\text { EndoTech) }\end{array}$ & $\begin{array}{l}\text { Founded in 1997, } \\
\text { incorporated in } 1998\end{array}$ & $\begin{array}{l}\text { The rigid borescope team of the Medison research } \\
\text { center was spun off; } 60 \% \text { stake in the business in } 1998 \text {. }\end{array}$ & D.J. Gang and K.J. Go & Endoscope \\
\hline 4 & BeMeMs Corp. & 2008 & - & $\begin{array}{l}\text { K.S. Joo and C.S. Ji } \\
\text { (Medison) }\end{array}$ & Mammo X-ray \\
\hline 5 & Medison Econet & 2001 & Econet division of Medison. & $\begin{array}{l}\text { J.S. Do, S.H. Kim, and D.S. } \\
\text { Cho }\end{array}$ & $\begin{array}{l}\text { Full body bone mineral } \\
\text { densitometry (BMD) }\end{array}$ \\
\hline 6 & $\begin{array}{c}\text { Medinus Co. Ltd. } \\
\text { (No longer in business) }\end{array}$ & 1998 & The MRI division of Medison was spun off. & & MRI \\
\hline 7 & Medison X-ray & 2001 & Parts of X-rays. & H.S. Lee & X-ray \\
\hline 8 & Welson EndoTech & 1997 & Division. & Y.J. Jee & $\begin{array}{l}\text { Endoscope medical } \\
\text { device }\end{array}$ \\
\hline 9 & Surtech Co. Ltd. & 1999 & Functional department $18.0 \%$ (2000). & D.J. Kim (now) & Medical device A/S \\
\hline 10 & $\begin{array}{l}\text { M2Comm } \\
\text { (renamed from } \\
\text { M2Community) }\end{array}$ & 1999 & $\begin{array}{l}\text { The marketing department of Medison was spun off; } \\
50 \% \text { stake in the business in } 2000 \text {. }\end{array}$ & B.I. Cho & $\begin{array}{l}\text { Medical marketing } \\
\text { agency, mobile business, } \\
\text { various solutions }\end{array}$ \\
\hline 11 & IT@Venture (closed) & 1999 & $\begin{array}{l}\text { The computer team of Medison was spun off; } 17.2 \% \\
\text { stake in the business in } 2000 \text {. }\end{array}$ & - & $\begin{array}{c}\text { Medison } \\
\text { Computing Department }\end{array}$ \\
\hline 12 & Future Communication & 1998 & $\begin{array}{l}\text { The public relations team of Medison was spun off; } \\
10 \% \text { stake in the business in } 2000 \text {. }\end{array}$ & - & $\begin{array}{l}\text { Medison public relation } \\
\text { (PR) }\end{array}$ \\
\hline
\end{tabular}

Source: In-depth interview results; internal material of the Korea Creative Economy Research Network; Reference [74]. 


\section{Appendix D.}

Table A3. Medison's venture investment list.

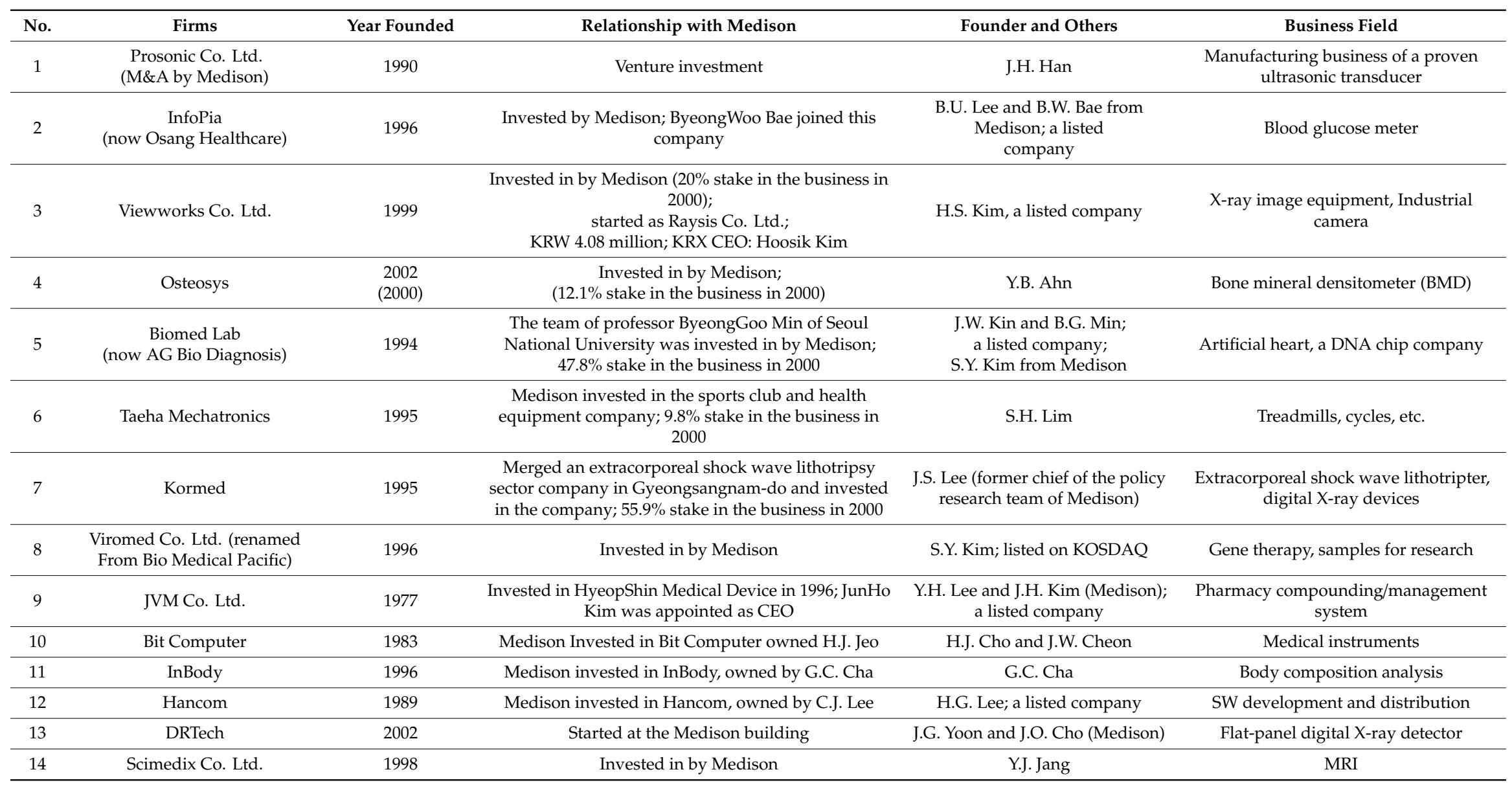


Table A3. Cont.

\begin{tabular}{|c|c|c|c|c|c|}
\hline No. & Firms & Year Founded & Relationship with Medison & Founder and Others & Business Field \\
\hline 15 & Softcamp Co. Ltd. & 1999 & Invested in by Medison & H.K. Bae & $\begin{array}{l}\text { Digital rights management (DRM), web } \\
\text { security, keyboard software }\end{array}$ \\
\hline 16 & Cygenic & 1999 & Invested in by Medison & H.S. Lee & $\begin{array}{l}\text { New drug for dementia/disease } \\
\text { treatment with natural substances, } \\
\text { health-functional foods }\end{array}$ \\
\hline 17 & $\begin{array}{c}\text { Medichems } \\
\text { (no longer operating) }\end{array}$ & 1997 & $\begin{array}{l}\text { Invested in by Medison; } 43.3 \% \text { stake in the business in } \\
\qquad 2000\end{array}$ & S.H. Kang (Currently) & Urea Breath Test (UBT) \\
\hline 18 & $\begin{array}{l}\text { Muhan Investment (no longer } \\
\text { operating) }\end{array}$ & 1996 & $\begin{array}{l}\text { Invested in by Medison; } 22.9 \% \text { stake in the business in } \\
\qquad 2000\end{array}$ & D.M Park (Currently) & Start-up investment \\
\hline
\end{tabular}

Source: in-depth interview results; internal material of the Korea Creative Economy Research Network; Reference [74]. 


\section{Appendix E.}

Table A4. Medison's joint venture list.

\begin{tabular}{|c|c|c|c|c|c|}
\hline No. & Firms & $\begin{array}{c}\text { Year } \\
\text { Founded }\end{array}$ & $\begin{array}{l}\text { Relationship with } \\
\text { Medison }\end{array}$ & Founder and Others & Business Field \\
\hline 1 & $\begin{array}{c}\text { Prosonic Co., Ltd. } \\
\text { (Daewon Electronics) } \\
\text { (merged into Medison) } \\
\text { JV co-investment }\end{array}$ & 1990 & $\begin{array}{l}\text { An outside venture } \\
\text { company of Medison, } \\
\text { founded through } \\
\text { joint investment; } \\
38.7 \% \text { stake in the } \\
\text { business in } 2000\end{array}$ & $\begin{array}{l}\text { J.H. Han; a listed } \\
\text { company }\end{array}$ & $\begin{array}{l}\text { Probe ultrasonic } \\
\text { transducer }\end{array}$ \\
\hline 2 & $\begin{array}{c}\text { Mediface } \\
\text { (renamed Infinitt) }\end{array}$ & 2002 & $\begin{array}{l}\text { Merger or Mediface } \\
\text { and 3DMed; } 52 \% \\
\text { stake in the business } \\
\text { in } 2000\end{array}$ & $\begin{array}{l}\text { G.T. Hong, D.W. Kim } \\
\text { S.J. Lee, and S.W. } \\
\text { Choi from Medison; } \\
\text { a listed company }\end{array}$ & $\begin{array}{c}\text { SW development } \\
\text { and distribution, } \\
\text { PACS }\end{array}$ \\
\hline 3 & Medilink Co. Ltd. & 2000 & $\begin{array}{l}\text { Joint venture; } 25.0 \% \\
\text { stake in the business } \\
\text { in } 2000\end{array}$ & $\begin{array}{l}\text { H.O. Woo and M.S. } \\
\text { Kim (Medison) }\end{array}$ & $\begin{array}{c}\text { Medical } \\
\text { consumables } \\
\text { distribution } \\
\text { company Medical } \\
\text { B2B }\end{array}$ \\
\hline 4 & $\begin{array}{l}\text { Biosys Co. Ltd. } \\
\text { extinguished }\end{array}$ & 1996 & $\begin{array}{c}\text { Stake: Sein } \\
\text { Electronics }(30 \%)+ \\
\text { Medison }(30 \%)\end{array}$ & $\begin{array}{l}\text { D.J. Gang, Sein } \\
\text { Electronics, and } \\
\text { invested in by } \\
\text { Medison }\end{array}$ & Biosignal diagnosis \\
\hline 5 & Korea Internet Holdings & 2000 & $\begin{array}{l}\text { Joint venture; } 20 \% \\
\text { stake in the business } \\
\text { in (2000) }\end{array}$ & $\begin{array}{l}\text { Medison, JV, MiRae, } \\
\text { and others; eight } \\
\text { firms co-invested }\end{array}$ & $\begin{array}{l}\text { Internet venture } \\
\text { holding company }\end{array}$ \\
\hline 6 & $\begin{array}{l}\text { Cyber KAIST } \\
\text { (extinguished) }\end{array}$ & 2000 & $\begin{array}{c}\text { Invested in by } \\
\text { Medison; } 30 \% \text { stake } \\
\text { in the business in } \\
2000\end{array}$ & $\begin{array}{l}\text { Medison and JV } \\
\text { co-invested }\end{array}$ & Online education \\
\hline 7 & EZMedicom Co. Ltd. & 2000 & & $\begin{array}{l}\text { Medison and JV } \\
\text { co-invested }\end{array}$ & $\begin{array}{c}\text { Medical consumable } \\
\text { distribution, supply } \\
\text { chain management } \\
\text { (SCM) }\end{array}$ \\
\hline
\end{tabular}

Source: in-depth interview results; internal material of the Korea Creative Economy Research Network [74]. 


\section{Appendix F.}

Table A5. Reinforcing and balancing loops of the open innovation serial entrepreneurship model.

\begin{tabular}{|c|c|c|}
\hline Feedback & Feedback Effect & Path \\
\hline $\begin{array}{c}<\mathrm{R}>\text { 'Serial Entrepreneurship' Self- } \\
\text { Reinforcing } \\
\text { (R-SE1): Reinforcing }\end{array}$ & $\begin{array}{l}\text { Mutual reinforcement between } \\
\text { serial entrepreneurship and } \\
\text { performance }\end{array}$ & $\begin{array}{c}\text { Serial Entrepreneurship } \uparrow \rightarrow \\
\text { Performance } \uparrow \rightarrow \text { Serial } \\
\text { Entrepreneurship } \uparrow\end{array}$ \\
\hline $\begin{array}{c}<\mathrm{R}>\text { 'Serial Entrepreneurship' } \\
\text { Self-Reinforcing through } \\
\text { 'Emergence' } \\
\text { (R-SE2): Reinforcing }\end{array}$ & $\begin{array}{l}\text { Mutual reinforcement between } \\
\text { serial entrepreneurship, } \\
\text { emergence by open innovation } \\
\text { (OI), and performance }\end{array}$ & $\begin{array}{c}\text { Serial Entrepreneurship } \uparrow \rightarrow \\
\text { Emergence by OI } \uparrow \rightarrow \\
\text { Performance } \uparrow \rightarrow \text { Serial } \\
\text { Entrepreneurship } \uparrow\end{array}$ \\
\hline $\begin{array}{c}<\text { B }>\text { 'Serial Entrepreneurship' } \\
\text { Self-Restriction because of } \\
\text { 'Complexity' } \\
\text { (B-SE1): Balancing }\end{array}$ & $\begin{array}{l}\text { Self-restriction between serial } \\
\text { entrepreneurship, complexity by } \\
\text { OI, and performance }\end{array}$ & $\begin{array}{c}\text { Serial Entrepreneurship } \uparrow \rightarrow \\
\text { Complexity by OI } \uparrow \rightarrow \\
\text { Performance } \downarrow \rightarrow \text { Serial } \\
\text { Entrepreneurship } \downarrow\end{array}$ \\
\hline $\begin{array}{c}<\mathrm{R}>\text { 'OI Channel' } \\
\text { Self-Reinforcing } 1 \\
\text { (R-Ch1): Reinforcing }\end{array}$ & $\begin{array}{c}\text { Mutual reinforcement between OI } \\
\text { channel, serial entrepreneurship, } \\
\text { emergence by OI, and } \\
\text { performance }\end{array}$ & $\begin{array}{c}\text { Open Innovation Channel } \uparrow \rightarrow \\
\text { Serial Entrepreneurship } \uparrow \rightarrow \\
\text { Emergence by OI } \uparrow \rightarrow \\
\text { Performance } \uparrow \rightarrow \text { Open } \\
\text { Innovation Channel } \uparrow\end{array}$ \\
\hline $\begin{array}{c}<\mathrm{R}>\text { 'OI Channel' } \\
\text { Self-Reinforcing } 2 \\
\text { (R-Ch2): Reinforcing }\end{array}$ & $\begin{array}{l}\text { Mutual reinforcement between OI } \\
\text { channel, emergence by OI, and } \\
\text { performance }\end{array}$ & $\begin{array}{c}\text { Open Innovation Channel } \uparrow \rightarrow \\
\text { Emergence by OI } \uparrow \rightarrow \\
\text { Performance } \uparrow \rightarrow \text { Open } \\
\text { Innovation Channel } \uparrow\end{array}$ \\
\hline $\begin{array}{c}<\mathrm{R}>\text { 'OI Channel' } \\
\text { Self-Reinforcing } 3 \\
\text { (R-Ch3): Reinforcing }\end{array}$ & $\begin{array}{l}\text { Mutual reinforcement between OI } \\
\text { channel, serial entrepreneurship, } \\
\text { and performance }\end{array}$ & $\begin{array}{c}\text { Open Innovation Channel } \uparrow \rightarrow \\
\text { Serial Entrepreneurship } \uparrow \rightarrow \\
\text { Performance } \uparrow \rightarrow \text { Open } \\
\text { Innovation Channel } \uparrow\end{array}$ \\
\hline $\begin{array}{c}<\mathrm{B}>\text { 'OI Channel' } \\
\text { Restriction } 1 \text { because of } \\
\text { 'Complexity' } \\
\text { (B-Ch1): Balancing }\end{array}$ & $\begin{array}{c}\text { Self-restriction between OI } \\
\text { channel, serial entrepreneurship, } \\
\text { complexity by OI, and } \\
\text { performance }\end{array}$ & $\begin{array}{c}\text { Open Innovation Channel } \uparrow \rightarrow \\
\text { Serial Entrepreneurship } \uparrow \rightarrow \\
\text { Complexity by OI } \uparrow \rightarrow \\
\text { Performance } \downarrow \rightarrow \text { Open } \\
\text { Innovation Channel } \downarrow\end{array}$ \\
\hline $\begin{array}{c}<\mathrm{R}>\text { 'OI Culture' } \\
\text { Reinforcing } 1 \\
\text { (R-Cu1): Reinforcing of Growth } \\
\text { through the usage of } \\
\text { 'Institutionalization of OI Culture' }\end{array}$ & $\begin{array}{l}\text { Reinforcement of the whole } \\
\text { process of growth using OI culture: } \\
\text { mutual reinforcement between } \\
\text { institute of OI culture, complexity } \\
\text { by OI, and performance }\end{array}$ & $\begin{array}{c}\text { Institutionalization of Open } \\
\text { Innovation Culture } \uparrow \rightarrow \\
\text { Complexity by OI } \downarrow \rightarrow \\
\text { Performance } \uparrow \rightarrow \\
\text { Institutionalization of Open } \\
\text { Innovation Culture } \uparrow \\
\end{array}$ \\
\hline $\begin{array}{c}<\mathrm{R}>\text { 'OI Culture' } \\
\text { Reinforcing } 2 \\
(\mathrm{R}-\mathrm{Cu} 2) \text { : Reinforcing between } \\
\text { institutionalization of OI Culture, } \\
\text { serial entrepreneurship, and } \\
\text { Performance }\end{array}$ & $\begin{array}{l}\text { Mutual reinforcement between } \\
\text { institutionalization of OI culture, } \\
\text { serial entrepreneurship, and } \\
\text { performance }\end{array}$ & $\begin{array}{c}\text { Institutionalization of Open } \\
\text { Innovation Culture } \uparrow \rightarrow \text { Serial } \\
\text { Entrepreneurship } \uparrow \rightarrow \\
\text { Performance } \uparrow \rightarrow \\
\text { Institutionalization of Open } \\
\text { Innovation Culture } \uparrow\end{array}$ \\
\hline
\end{tabular}

\section{References}

1. Lee, M.; Yun, J.J.; Pyka, A.; Won, D.; Kodama, F.; Schiuma, G.; Park, H.; Jeon, J.; Park, K.; Jung, K.; et al. How to respond to the Fourth Industrial Revolution, or the Second Information Technology Revolution? Dynamic new combinations between technology, market, and society through open innovation. J. Open Innov. Technol. Mark. Complex. 2018, 4, 21. [CrossRef]

2. Mazzucato, M. The innovative state: Governments should make market, not just fix them. Foreign Aff. 2015, 94,61 . 
3. Rifkin, J. The Zero Marginal Cost Society: The Internet of Things, the Collaborative Commons, and the Eclipse of Capitalism; St. Martin's Press: New York, NY, USA, 2014.

4. Senor, D.; Singer, S. Start-Up Nation: The Story of Israel's Economic Miracle; Random House Digital, Inc.: New York, NY, USA, 2011.

5. Hyytinen, A.; Pajarinen, M.; Rouvinen, P. Does innovativeness reduce startup survival rates? J. Bus. Ventur. 2015, 30, 564-581. [CrossRef]

6. Hyytinen, A.; Ilmakunnas, P. What distinguishes a serial entrepreneur? Ind. Corp. Chang. 2007, 16, 793-821. [CrossRef]

7. Hooge, S.; Dalmasso, C.; Garcias, F. Is intrapreneurship scalable? The challenge of managing a massive internal startup call. In Proceedings of the R\&D Management Conference 2018, Milan, Italy, 30 June-4 July 2018.

8. Parker, S.C. Intrapreneurship or entrepreneurship? J. Bus. Ventur. 2011, 26, 19-34. [CrossRef]

9. Yun, J.J. How do we conquer the growth limits of capitalism? Schumpeterian dynamics of open innovation. J. Open Innov. Technol. Mark. Complex. 2015, 1, 17. [CrossRef]

10. Yun, J.J.; Won, D.; Park, K. Entrepreneurial cyclical dynamics of open innovation. J. Evol. Econ. 2018, 28, 1151-1174. [CrossRef]

11. Schumpeter, J.A. Business Cycles; McGraw-Hill: New York, NY, USA, 1939; Volume 1.

12. Schumpeter, J.A. Capitalism, Socialism and Democracy; Routledge: Abingdon, UK, 1942.

13. Wright, M.; Robbie, K.; Ennew, C. Venture capitalists and serial entrepreneurs. J. Bus. Ventur. 1997, 12, 227-249. [CrossRef]

14. Twomey, R. The PayPal mafia. Fortune 2007, 156, 96.

15. Lee, J.; Park, S.; Chang, H. Growth of startups and spinout under schumpeterian competition: The Medison case. Ventur. Manag. Res. 2000, 3, 81-108.

16. Kim, D.-J. Falls from grace and lessons from failure: Daewoo and Medison. Long Range Plan. 2007, 40, 446-464. [CrossRef]

17. Yun, J.J.; Park, K.; Kim, J.; Yang, J. Open innovation effort, entrepreneurship orientation and their synergies onto innovation performance in SMEs of Korea. Sci. Technol. Soc. 2016, 21, 366-390. [CrossRef]

18. Chesbrough, H.W. Open Innovation: The New Imperative for Creating and Profiting from Technology; Harvard Business Press: Boston, MA, USA, 2003.

19. Enkel, E.; Gassmann, O. Driving open innovation in the front end. In Proceedings of the 7th European Academy of Management Conference (EURAM), Paris, France, 16-19 May 2007.

20. Westhead, P.; Wright, M.; Binks, M.; Ucbasaran, D. Novice, serial and portfolio entrepreneur behaviour and contributions. Small Bus. Econ. 2005, 25, 109-132. [CrossRef]

21. Wright, M.; Robbie, K.; Ennew, C. Serial entrepreneurs. Br. J. Manag. 1997, 8, 251-268. [CrossRef]

22. Seidman, I. Interviewing as Qualitative Research: A Guide for Researchers in Education and the Social Sciences; Teachers College Press: New York, NY, USA, 2006.

23. Barriball, K.L.; While, A. Collecting data using a semi-structured interview: A discussion paper. J. Adv. Nurs. Inst. Subscr. 1994, 19, 328-335. [CrossRef] [PubMed]

24. McIntosh, M.J.; Morse, J.M. Situating and constructing diversity in semi-structured interviews. Glob. Qual. Nurs. Res. 2015, 2. [CrossRef] [PubMed]

25. Creswell, J.W.; Poth, C.N. Qualitative Inquiry and Research Design: Choosing among Five Approaches; Sage Publications: Thousand Oaks, CA, USA, 2017.

26. Gartner, W.B. "Who is an entrepreneur?" is the wrong question. Am. J. Small Bus. 1988, 12, 11-32. [CrossRef]

27. Boutillier, S. Finance, State and Entrepreneurship in the Contemporary Economy, in Powerful Finance and Innovation Trends in a High-Risk Economy; Springer: Berlin, Germany, 2008; pp. 66-87.

28. Boutillier, S.; Laperche, B.; Uzunidis, D. La Légende de L'entrepreneur: Le Capital Social, Comment Vient L'esprit D'entreprise; FeniXX: Houston, TX, USA, 1999.

29. Kirzner, I.M. Entrepreneurial discovery and the competitive market process: An Austrian approach. J. Econ. Lit. 1997, 35, 60-85.

30. Kirzner, I.M. The alert and creative entrepreneur: A clarification. Small Bus. Econ. 2009, 32, 145-152. [CrossRef]

31. Rao, A. How to grow innovation culture in Genesee Valley. Rochester Bus. J. 2008, 24, Art. 20.

32. Hoye, K.; Pries, F. 'Repeat commercializers,'the 'habitual entrepreneurs' of university-industry technology transfer. Technovation 2009, 29, 682-689. [CrossRef] 
33. Baumol, W.J.; Litan, R.E.; Schramm, C.J. Good Capitalism, Bad Capitalism, and the Economics of Growth and Prosperity; Yale University Press: New Haven, CT, USA, 2007.

34. Uzunidis, D.; Boutillier, S. Globalization of R \& D and network innovation: What do we learn from the evolutionist theory? J. Innov. Econ. Manag. 2012, 2, 23-52.

35. Gassmann, O.; Enkel, E. Towards a theory of open innovation: Three core process archetypes. In Proceedings of the R\&D Management Conference (RADMA) 2004, Lissabon, Portugal, 7-9 July 2004.

36. Docherty, M. Primer on open innovation: Principles and practice. PDMA Vis. 2006, 30, 13-17.

37. Mortara, L.; Minshall, T. How do large multinational companies implement open innovation? Technovation 2011, 31, 586-597. [CrossRef]

38. Vohora, A.; Wright, M.; Lockett, A. Critical junctures in the development of university high-tech spinout companies. Res. Policy 2004, 33, 147-175. [CrossRef]

39. Van de Vrande, V.; de Jong, J.P.J.; Vanhaverbekec, W.; de Rochemon, M. Open innovation in SMEs: Trends, motives and management challenges. Technovation 2009, 29, 423-437. [CrossRef]

40. West, J.; Vanhaverbeke, W.; Chesbrough, H. Open innovation: A research agenda. In Open Innovation: Researching a New Paradigm; Oxford University Press: Oxford, UK, 2006; pp. 285-307.

41. Kortum, S.; Lerner, J. Does venture capital spur innovation? In Entrepreneurial Inputs and Outcomes: New Studies of Entrepreneurship in the United States; Emerald Group Publishing Limited: Bingley, UK, 2001; pp. 1-44.

42. Vanhaverbeke, W.; van de Vrande, V.; Chesbrough, H. Understanding the advantages of open innovation practices in corporate venturing in terms of real options. Creat. Innov. Manag. 2008, 17, 251-258. [CrossRef]

43. Hochberg, Y.V.; Ljungqvist, A.; Lu, Y. Whom you know matters: Venture capital networks and investment performance. J. Financ. 2007, 62, 251-301. [CrossRef]

44. Chesbrough, H.; Schwartz, K. Innovating business models with co-development partnerships. Res. Technol. Manag. 2007, 50, 55-59. [CrossRef]

45. Park, S.H.; Russo, M.V. When competition eclipses cooperation: An event history analysis of joint venture failure. Manag. Sci. 1996, 42, 875-890. [CrossRef]

46. Yiu, D.; Makino, S. The choice between joint venture and wholly owned subsidiary: An institutional perspective. Organ. Sci. 2002, 13, 667-683. [CrossRef]

47. Reuer, J.J.; Koza, M.P. Asymmetric information and joint venture performance: Theory and evidence for domestic and international joint ventures. Strateg. Manag. J. 2000, 21, 81-88. [CrossRef]

48. Pothukuchi, V.; Damanpour, F.; Choi, J.; Chen, C.C.; Park, S.H. National and organizational culture differences and international joint venture performance. J. Int. Bus. Stud. 2002, 33, 243-265. [CrossRef]

49. Dittrich, K.; Duysters, G. Networking as a means to strategy change: The case of open innovation in mobile telephony. J. Prod. Innov. Manag. 2007, 24, 510-521. [CrossRef]

50. Huizingh, E.K. Open innovation: State of the art and future perspectives. Technovation 2011, 31, 2-9. [CrossRef]

51. Katz, R.; Allen, T.J. Investigating the Not Invented Here (NIH) syndrome: A look at the performance, tenure, and communication patterns of $50 \mathrm{R} \&$ D Project Groups. REd Manag. 1982, 12, 7-20.

52. Gassmann, O.; Enkel, E.; Chesbrough, H. The future of open innovation. REd Manag. 2010, 40, $213-221$.

53. Herzog, P.; Leker, J. Open and closed innovation-different innovation cultures for different strategies. Int. J. Technol. Manag. 2010, 52, 322-343. [CrossRef]

54. Herzog, P. Open and Closed Innovation: Different Cultures for Different Strategies; Springer Science \& Business Media: Heidelberg, Germany, 2001.

55. Yun, J.; Won, D.; Park, K. Dynamics from open innovation to evolutionary change. J. Open Innov. Technol. Mark. Complex. 2016, 2, 7. [CrossRef]

56. Aquilani, B.; Silvestri, C.; Ruggieri, A.; Gatti, C. A systematic literature review on total quality management critical success factors and the identification of new avenues of research. TQM J. 2017, 29, 184-213. [CrossRef]

57. Martins, E.C.; Terblanche, F. Building organisational culture that stimulates creativity and innovation. Eur. J. Innov. Manag. 2003, 6, 64-74. [CrossRef]

58. Berglund, H.; Sandström, C. Business model innovation from an open systems perspective: Structural challenges and managerial solutions. Int. J. Prod. Dev. 2013, 18, 274-285. [CrossRef]

59. Herbig, P.A.; Miller, J.C. Culture and technology: Does the traffic move in both directions? J. Glob. Mark. 1993, 6, 75-104. [CrossRef]

60. Curley, M.; Salmelin, B. Open Innovation 2.0: The New Mode of Digital Innovation for Prosperity and Sustainability; 
61. Allen, J.W. Capital markets and corporate structure: The equity carve-outs of thermo electron. J. Financ. Econ. 1998, 48, 99-124. [CrossRef]

62. Lockett, A.; Wright, M. Resources, capabilities, risk capital and the creation of university spin-out companies. Res. Policy 2005, 34, 1043-1057. [CrossRef]

63. Wolcott, R.C.; Lippitz, M.J. The four models of corporate entrepreneurship. MIT Sloan Manag. Rev. 2007, 49,75 .

64. Witt, U. Capitalism as a complex adaptive system and its growth. J. Open Innov. Technol. Mark. Complex. 2017, 3, 12. [CrossRef]

65. Martinez, M.G. Open Innovation in the Food and Beverage Industry; Elsevier: Amsterdam, The Netherlands, 2013.

66. Greco, M.; Grimaldi, M.; Cricelli, L. An analysis of the open innovation effect on firm performance. Eur. Manag. J. 2016, 34, 501-516. [CrossRef]

67. Kobarg, S.; Stumpf-Wollersheim, J.; Welpe, I.M. More is not always better: Effects of collaboration breadth and depth on radical and incremental innovation performance at the project level. Res. Policy 2019, 48, 1-10. [CrossRef]

68. Sterman, J.D. Business Dynamics: Systems Thinking and Modeling for a Complex World; Irwin McGraw-Hill: Boston, MA, USA, 2000.

69. Richardson, G.P. Problems with causal-loop diagrams. Syst. Dyn. Rev. 1986, 2, 158-170. [CrossRef]

70. Groesser, S.N.; Schaffernicht, M. Mental models of dynamic systems: Taking stock and looking ahead. Syst. Dyn. Rev. 2012, 28, 46-68. [CrossRef]

71. Dougherty, D. Taking advantage of emergence for complex innovation eco-systems. J. Open Innov. Technol. Mark. Complex. 2017, 3, 14. [CrossRef]

72. Glińska, E.; Siemieniako, D. Binge drinking in relation to services-Bibliometric analysis of scientific research directions. Eng. Manag. Prod. Serv. 2018, 10, 45-54. [CrossRef]

73. Siderska, J.; Jadaan, K.S. Cloud manufacturing: A service-oriented manufacturing paradigm. A review paper. Eng. Manag. Prod. Serv. 2018, 10, 22-31. [CrossRef]

74. MinHwa, L. Medison Mafia Story; KCERN: Seoul, Korea, 2016.

(C) 2019 by the authors. Licensee MDPI, Basel, Switzerland. This article is an open access article distributed under the terms and conditions of the Creative Commons Attribution (CC BY) license (http://creativecommons.org/licenses/by/4.0/). 